\title{
Nitrogen isotopes in bulk marine sediment: linking seafloor observations with subseafloor records
}

\author{
J.-E. Tesdal ${ }^{1, *}$, E. D. Galbraith ${ }^{1}$, and M. Kienast ${ }^{2}$ \\ ${ }^{1}$ Department of Earth and Planetary Sciences, McGill University, Montreal, Quebec, Canada \\ ${ }^{2}$ Department of Oceanography, Dalhousie University, Halifax, Nova Scotia, Canada \\ *now at: School of Earth and Ocean Sciences, University of Victoria, Victoria, British Columbia, Canada
}

Correspondence to: E. D. Galbraith (eric.galbraith@mcgill.ca)

Received: 15 March 2012 - Published in Biogeosciences Discuss.: 30 March 2012

Revised: 2 November 2012 - Accepted: 26 November 2012 - Published: 9 January 2013

\begin{abstract}
The stable isotopes of nitrogen offer a unique perspective on changes in the nitrogen cycle, past and present. However, the presence of multiple forms of nitrogen in marine sediments can complicate the interpretation of bulk nitrogen isotope measurements. Although the large-scale global patterns of seafloor $\delta^{15} \mathrm{~N}$ have been shown to match process-based expectations, small-scale heterogeneity on the seafloor, or alterations of isotopic signals during translation into the subseafloor record, could obscure the primary signals. Here, a public database of nitrogen isotope measurements is described, including both seafloor and subseafloor sediment samples ranging in age from modern to the Pliocene, and used to assess these uncertainties. In general, good agreement is observed between neighbouring seafloor sites within a $100 \mathrm{~km}$ radius, with $85 \%$ showing differences of $<1 \%$. There is also a good correlation between the $\delta^{15} \mathrm{~N}$ of the shallowest $(<5 \mathrm{ka})$ subseafloor sediments and neighbouring seafloor sites within a $100 \mathrm{~km}$ radius $\left(R^{2}=0.83\right)$, which suggests a reliable translation of sediments into the buried sediment record. Meanwhile, gradual $\delta^{15} \mathrm{~N}$ decreases over multiple glacial-interglacial cycles appear to reflect post-depositional alteration in records from the deep sea (below $2000 \mathrm{~m}$ ). We suggest a simple conceptual model to explain these 100-kyr-timescale changes in well-oxygenated, slowly accumulating sediments, which calls on differential loss rates for pools of organic $\mathrm{N}$ with different $\delta^{15} \mathrm{~N}$. We conclude that bulk sedimentary nitrogen isotope records are reliable monitors of past changes in the marine nitrogen cycle at most locations, and could be further improved with a better understanding of systematic post-depositional alteration. Furthermore, geochemical or environmental criteria should
\end{abstract}

be developed in order to effectively identify problematic locations and to account for confounding influences where possible.

\section{Introduction}

Nitrogen is a critical nutrient element in marine ecosystems, limiting the growth of marine life over most of the oceans (Falkowski, 1997). The supply of bioavailable nitrogen is currently being modified anthropogenically in multiple ways (Gruber and Galloway, 2008). Future changes in the nitrogen cycle have the potential to significantly impact the oceanic nutrient regime, with significant implications for the marine ecosystem, but uncertainty remains regarding how sensitive the nitrogen cycle will prove to be.

Measurements of nitrogen isotopes in marine sediments provide a unique way of understanding the past and present marine nitrogen cycle and its relationship to climate change. The nitrogen isotope ratio $\left({ }^{15} \mathrm{~N} /{ }^{14} \mathrm{~N}\right)$ in a sample is expressed relative to the nitrogen isotope composition of a standard, conventionally atmospheric nitrogen gas $\left(\delta^{15} \mathrm{~N}=\left(\left[{ }^{15} \mathrm{~N} /{ }^{14} \mathrm{~N}\right]_{\text {sample }} /\left[{ }^{15} \mathrm{~N} /{ }^{14} \mathrm{~N}\right]_{\text {air }}-1\right) \times 1000 \% o\right)$. Over the past two decades, the systematics of nitrogen isotopes in the ocean have become increasingly well understood, providing a sound theoretical basis for their interpretation (Altabet, 2006; Galbraith et al., 2008a). Meanwhile, scores of individual marine sedimentary $\delta^{15} \mathrm{~N}$ records have been published, spanning from the late Holocene to the early Pliocene.

The $\delta^{15} \mathrm{~N}$ of bulk marine sediment reflects three components: marine organic matter, terrestrial organic matter, and 
inorganic nitrogen. The latter is dominated by clay-bound $\mathrm{NH}_{4}^{+}$, and can be significant in areas of high clay input relative to organic matter sedimentation (Schubert and Calvert, 2001; Kienast et al., 2005). Terrestrial organic matter can also be significant in the vicinity of rivers or glacial discharge with high particulate loads (McKay et al., 2004), but tends to be overwhelmed by marine organic matter elsewhere (Altabet, 2006). Because we are generally interested in marine organic nitrogen, the terrestrial and inorganic sources are viewed as contaminants to be avoided.

The $\delta^{15} \mathrm{~N}$ of marine organic matter exported from the surface is equal to the isotopic composition of the nitrogen substrate supplied to the surface. A small fraction of this nitrogen is provided by local $\mathrm{N}_{2}$ fixation or atmospheric deposition, but the majority is supplied by upward transport from the subsurface nitrate reservoir. The isotopic composition of nitrate itself is determined by fractionation during the uptake of nitrate by phytoplankton (Needoba et al., 2004) and the conversion of bioavailable $\mathrm{N}$ to $\mathrm{N}_{2}$ gas by denitrification (including anammox) (Brandes and Devol, 1997). Both of these reactions are more rapid for ${ }^{14} \mathrm{~N}$ than for ${ }^{15} \mathrm{~N}$, leaving the residual nitrogen pool enriched in ${ }^{15} \mathrm{~N}$. The uptake fractionation of phytoplankton leads only to internal gradients in the ocean, with low values in nitrate-rich regions and high values in the nitrate-poor gyres (Galbraith et al., 2013), while the loss of ${ }^{14} \mathrm{~N}$ through denitrification causes the global fixed $\mathrm{N}$ pool to be enriched relative to its source $(\sim 5 \%$, Brandes and Devol, 2002). The sources of biologically available nitrogen to the ocean, from terrestrial inputs and marine $\mathrm{N}_{2}$ fixation, appear to cluster around 0\%o (Brandes and Devol, 2002; Knapp et al., 2010), though they remain poorly constrained.

Alteration of $\delta^{15} \mathrm{~N}$ from the primary marine signal to the preserved sedimentary value, parochially known as diagenesis, has long been recognized as a concern (Altabet and Francois, 1994). The $\delta^{15} \mathrm{~N}$ of sinking particles has been shown to vary in the water column with no clear relationship with water depth, suggesting heterogenous processes that vary in time and space (Robinson et al., 2012; Lourey et al., 2003). Yet, the global pattern of seafloor $\delta^{15} \mathrm{~N}$ shows broad similarities to that expected from both water column nitrate isotopic measurements and global isotope-biogeochemical models, showing that the material that reaches the seafloor is a better reflection of surface processes than the sinking particles would suggest (Robinson et al., 2012; Galbraith et al., 2013). Nonetheless, bulk $\delta^{15} \mathrm{~N}$ could be compromised either (1) by significant variability in seafloor $\delta^{15} \mathrm{~N}$ over small scales, rendering individual records suspect, or (2) if subseafloor sediments of the geological record do not faithfully represent the isotopic composition of their modern (seafloor) counterparts due to diagenetic alteration. Neither of these concerns can be easily addressed from individual records alone.

Here, we describe the first iteration of a global database of published marine bulk sediment $\delta^{15} \mathrm{~N}$ measurements, including both seafloor and subseafloor downcore sediments. The
Nitrogen Cycle in the Oceans, Past and Present (NICOPP) database is intended to aid in deciphering the overlapping isotopic factors over a broad range of timescales, while answering a call for more thorough data management within the geoscience community at large (Parsons et al., 2010). The compilation aims to include all published $\delta^{15} \mathrm{~N}$ records from marine sediments of any age retrieved from anywhere in a modern ocean basin (i.e. not including marine sediments now found on land). Some unpublished data are also included in the database. The current database includes only bulk sedimentary $\delta^{15} \mathrm{~N}$, which represents the isotopic composition of all combustible nitrogen in the sediment. Additional types of $\delta^{15} \mathrm{~N}$ measurements, such as species-specific $\delta^{15} \mathrm{~N}$ measurements (diatom, foraminifera, etc.), could be added in future. We anticipate that, by assembling all $\delta^{15} \mathrm{~N}$ records previously presented in the literature, the patterns of multiple nitrogen cycling processes will become clearer, local discrepancies more obvious, data gaps highlighted, and progress will be more efficiently made toward quantifying the fidelity with which sedimentary $\delta^{15} \mathrm{~N}$ tracks sinking and sedimented organic matter.

The goals of this paper are twofold: first, to provide a brief technical description of the NICOPP database for future investigators who will focus on specific aspects of the data therein; second, to use the database in order to evaluate the degree to which downcore sedimentary $\delta^{15} \mathrm{~N}$ records reflect the $\delta^{15} \mathrm{~N}$ of nearby core-top data, through a spatial comparison with neighbouring observations and a temporal comparison with observations throughout the Late Pleistocene. This provides a novel global view on spatial variability in $\delta^{15} \mathrm{~N}$ and diagenesis. We do not discuss detailed interpretations of the $\delta^{15} \mathrm{~N}$ records here as they inform past changes in the $\mathrm{N}$ cycle; this complex topic is left for other works to explore.

The sedimentary $\delta^{15} \mathrm{~N}$ database is available for use by the scientific community to assist in further research and analysis. The database will be updated as new records become available, and the authors welcome additional contributions.

\section{Database description}

All data represent measurements of dry, homogenized bulk sediment. Analytical methods have varied to some degree between laboratories and over time. Most measurements made prior to 1995 used the offline Dumas combustion method (Minagawa et al., 1984). Subsequent to 1995, most analyses were made using an elemental analyser, coupled to an isotope ratio mass spectrometer (IRMS) in a continuous flow mode, with a few exceptions (e.g. Agnihotri et al., 2003). Commonly used elemental analysers include the Carlo-Erba, Europa Euroboprep, and Fisons North America, while IRMS models include the Finnigan MAT, VG PRISM, Micromass Isoprime, and Thermo-Finnigan DELTA. In all cases, He is used as the carrier gas. Most analyses are calibrated with recognized standards (e.g. IAEA-N1, -N2, NIST 8548 or local 


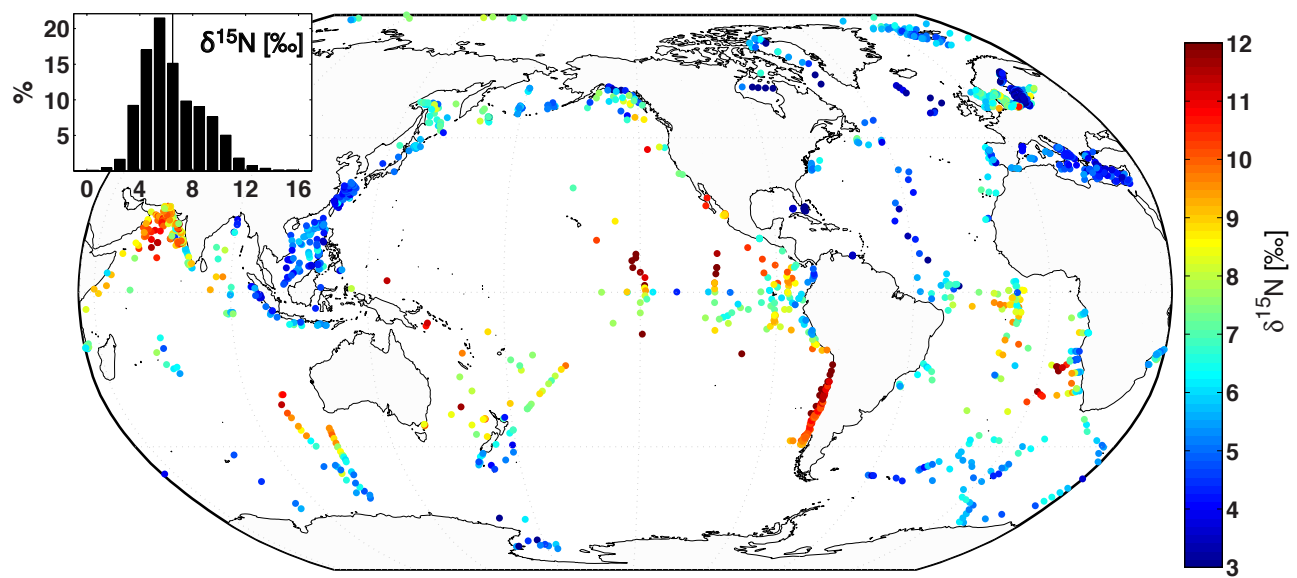

Fig. 1. Spatial distribution of surface sediment $\delta^{15} \mathrm{~N}$ samples. References for published data are provided on the web site. Unpublished data are from Galbraith et al. (2013) and this study. Inset: histogram of surface $\delta^{15} \mathrm{~N}$ (in 1-kyr bins). The vertical line indicates the mean of $6.7 \%$, higher than the average $\delta^{15} \mathrm{~N}$ of nitrate in the ocean $(\sim 5 \%$ o). Note the dataset is skewed towards heavier nitrogen isotopic composition.

air), and some laboratories supplement these with their own sediment standards.

The combusted material is dominated by marine organic matter at most locations, although there is significant contamination by clay-bound inorganic (Kienast et al., 2005) and terrigenous nitrogen (Schubert and Calvert, 2001) in some locations. Given the known problems with acidification of samples (Brodie et al., 2011), we flagged samples that had been acidified where possible, though acidification is not always reported. Reported errors for the bulk combustion method are generally better than $\pm 0.3 \%$ o for replicates.

The database is publicly available and can be accessed at http://www.ncdc.noaa.gov/paleo/pubs/nicopp/nicopp.html.

It may be expanded to include mineral-bound and compound-specific fractions in future.

\subsection{Seafloor sediments}

Thus far, the collection of seafloor sediment $\delta^{15} \mathrm{~N}$ contains more than 2300 sites, which include only real sediment measurements from any depth and region of the ocean seafloor (Fig. 1). Most of these sites (ca. 90\%) are multicores, giantbox cores, or core-tops of piston and gravity cores. There is some uncertainty about what time range the seafloor sediment samples represent. Very few seafloor $\delta^{15} \mathrm{~N}$ values have been associated with an actual age measurement, but we can assume that in low sedimentation regions samples represent a much longer timescale (order $10^{3} \mathrm{yr}$ ) compared with highsedimentation sites (order $10^{2} \mathrm{yr}$ ).

The seafloor $\delta^{15} \mathrm{~N}$ values range from 2.5 to $16.6 \%$ (Fig. 1, inset). The average isotopic composition is $6.7 \%$, higher than the average isotopic composition of nitrate in the ocean ( $\sim 5 \%$, Sigman et al., 1997, 1999). However, the dataset is positively skewed towards higher $\delta^{15} \mathrm{~N}$, such that the majority of sites have values centred at around 4 to $6 \%$ (Fig. 1, inset). Given the highly irregular sampling pattern (Fig. 1), a significant spatial bias is likely, and may partially explain the elevated mean value. However, it has been shown that the $\delta^{15} \mathrm{~N}$ of bulk nitrogen in well-oxygenated sediments of the deep sea is higher than the $\delta^{15} \mathrm{~N}$ of organic matter exported from the surface (Altabet and Francois, 1994), with a general increase of 0.75 per $\mathrm{km}$ water depth (Robinson et al., 2012; Galbraith et al., 2013). This is likely the primary explanation for the generally elevated seafloor $\delta^{15} \mathrm{~N}$.

The global map of seafloor $\delta^{15} \mathrm{~N}$ (Fig. 1) reveals regionally consistent patterns, aligned with large-scale oceanic features. As expected from prior work, regions of upwelling have lower $\delta^{15} \mathrm{~N}$ due to incomplete consumption of nitrate, while regions near zones of water column anoxia have higher $\delta^{15} \mathrm{~N}$ due to the preferential loss of ${ }^{14} \mathrm{~N}$ nitrate during denitrification. These patterns are discussed in detail elsewhere (Galbraith et al., 2008a and references therein).

\subsection{Subseafloor sediments}

The subseafloor database includes $\delta^{15} \mathrm{~N}$ measurements and corresponding sediment depths, as well as (where available) a published age model, nitrogen content $(\% \mathrm{~N})$, total organic carbon content $\left(\% \mathrm{C}_{\mathrm{org}}\right)$ and dry bulk density. We identified 173 subseafloor records for which bulk sedimentary $\delta^{15} \mathrm{~N}$ data exist (Table 1). We obtained $\delta^{15} \mathrm{~N}$ data for 153 core sites, while we could only obtain a complete set of ancillary measurements $\left(\% \mathrm{~N}, \% \mathrm{C}_{\mathrm{org}}\right.$, dry bulk density) for 14 of those core sites, while an additional 79 core sites have at least $\% \mathrm{~N}$ or $\% \mathrm{C}_{\text {org }}$. Age models were entered as published in the original references with no alteration (with a few exceptions where the age model was unavailable and needed to be regenerated from the original age control data).

The majority of subseafloor records are situated along the coast, where sedimentation rates are high and there has been greater confidence in the fidelity of sediment $\delta^{15} \mathrm{~N}$ (Thunell et al., 2004; Altabet et al., 1999). In addition, records are 


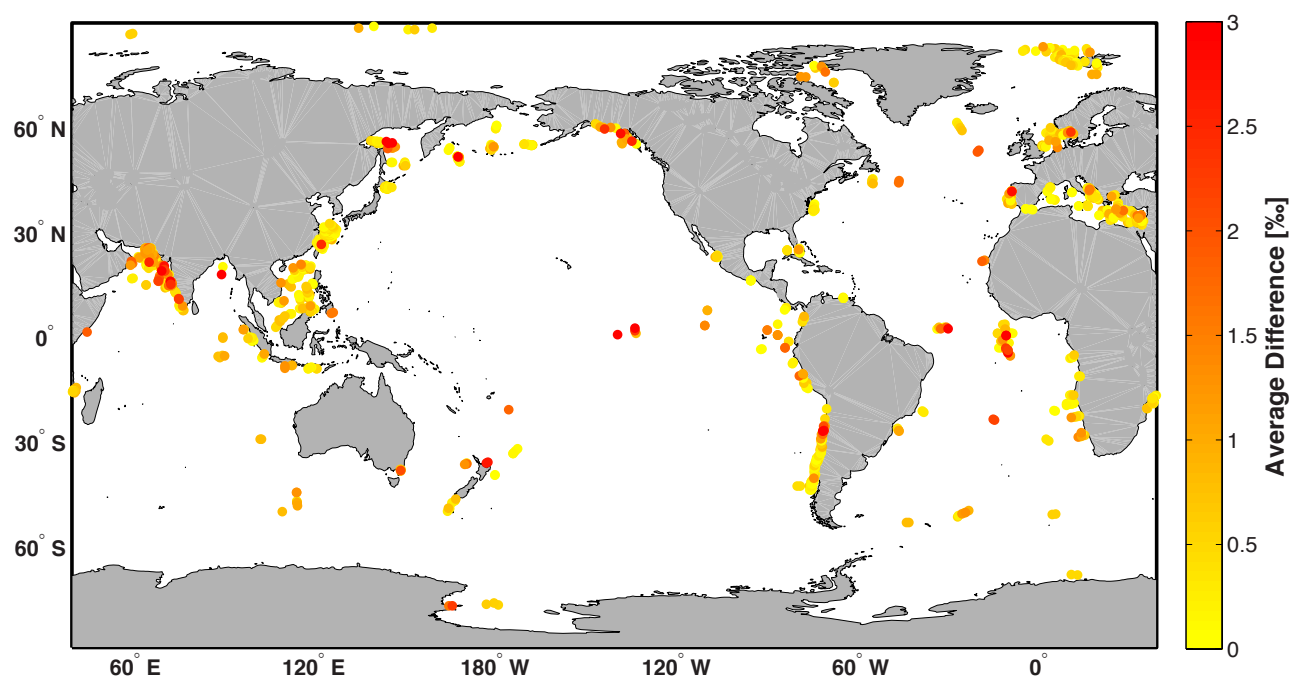

Fig. 2. Map of seafloor samples indicating the difference between the $\delta^{15} \mathrm{~N}$ of the sample and the mean $\delta^{15} \mathrm{~N}$ of its neighbours (within a $100 \mathrm{~km}$ radius). The differences are small for most of the available locations. Data points with larger differences are plotted on top of those with smaller differences, to highlight regions where high spatial variability exists.

concentrated at regions of interest, including those associated with coastal upwelling and/or suboxic conditions with water column denitrification. Thus, the database has a high degree of spatial bias. In particular, as illustrated in Figs. 2 and 3a, a considerable number of records are from the Arabian Sea $(17 \%)$, the South China Sea $(13 \%)$, the eastern equatorial Pacific (19\%), the west coasts of North (12\%) and South America (14\%), and the southwest coast of Africa (11\%). As in the case of surface sediment sampling (Fig. 1), we have vast regions of the ocean, especially in the Southern Hemisphere, where the spatial coverage of $\delta^{15} \mathrm{~N}$ records is very poor. There were no published downcore records found in the Bay of Bengal, the southwest Pacific or, surprisingly, most of the North Atlantic (Fig. 3).

The temporal coverage of the available $\delta^{15} \mathrm{~N}$ records shows, unsurprisingly, a strong bias toward the more recent timescales of the Holocene and Late Pleistocene periods. We find the maximum number of records between 5 and $20 \mathrm{ka}$ before present (BP) (Fig. 4b). As one might expect, most of the records that go beyond the last glacial-interglacial cycle (i.e. the last $\sim 120 \mathrm{ka}$ ) have the disadvantage of being considerably coarser in resolution. In fact, the average sampling frequency for the most recent times is as high as five measurements per kyr, dropping to less than one measurement per kyr by about $65 \mathrm{ka}$, and to one measurement every $4 \mathrm{kyr}$ by $100 \mathrm{ka}$ BP. To compare these unequally spaced time series of $\delta^{15} \mathrm{~N}$ records quantitatively, we created a common age axis by interpolating all $\delta^{15} \mathrm{~N}$ records.

\section{Spatial and temporal consistency in sedimentary $\delta^{15} N$}

\subsection{Consistency at the seafloor}

According to Fig. 1, some regions display strong gradients of surface $\delta^{15} \mathrm{~N}$, such as in the eastern Arabian Sea, where gradients as large as $4.5 \%$ occur within $\sim 1^{\circ}$ of latitude/longitude. In order to more clearly identify regions of pronounced small-scale variability, we analysed the similarity of neighbouring seafloor samples within $100 \mathrm{~km}$ of each other (Fig. 2). This variance could be due to oceanic fronts generating gradients in the $\delta^{15} \mathrm{~N}$ of exported organic matter, sedimentary processes causing heterogeneity at the seafloor, or even to discrepancies in measurement techniques. However, apart from a few regions (most notably the eastern Arabian Sea, central equatorial Pacific, and central equatorial Atlantic) the difference between neighbouring seafloor samples is small: less than the measurement error of $0.3 \%$ in $43 \%$ of samples, and less than $1 \%$ in $85 \%$ of samples.

The general similarity of neighbours could be surprising, given the potential complexity of bulk $\delta^{15} \mathrm{~N}$ in marine sediments. The compilation here suggests that, in most of the ocean, spatial averaging by turbulent ocean circulation conspires with temporal averaging over centuries of deposition such that seafloor sediment generally provides a consistent reflection of the surrounding environment on a scale of order of $100 \mathrm{~km}$, in $85 \%$ of cases. This consistency does not mean that the seafloor bulk $\delta^{15} \mathrm{~N}$ necessarily reflects exported marine organic $\delta^{15} \mathrm{~N}$, as contamination by terrestrial $\mathrm{N}$ occurs in some places (Kienast et al., 2005; Meckler et al., 2011), a concern that must be evaluated on a site-specific basis. 
Table 1. List of $\delta^{15} \mathrm{~N}$ records in the NICOPP database (as of 21 September 2012).

\begin{tabular}{|c|c|c|c|c|c|c|}
\hline Core name & Latitude & Longitude & Depth (m) & Core type & Timespan (ka) & Reference \\
\hline AII 125-8 GGC-55 & 27.47 & -112.11 & 820 & Gravity & & Pride et al. (1999) \\
\hline AII 125-8 JPC-44 & 27.90 & -111.66 & 655 & Piston & & Pride et al. (1999) \\
\hline AII 125-8 JPC-48 & 27.94 & -111.80 & 530 & Piston & & Pride et al. (1999) \\
\hline AII 125-8 JPC-56 & 27.47 & -112.10 & 818 & Piston & 5.5 to 16.8 & Pride et al. (1999) \\
\hline $\mathrm{A} 1 \mathrm{C} 1$ & 41.10 & -73.33 & 9 & Gravity & 0 to 0.9 & Altabet (2007) \\
\hline B1 GGC1 & 41.17 & -73.08 & 7 & Gravity & 0 to 4.0 & Altabet (2007) \\
\hline BJ8-03-102GGC & 1.00 & 127.72 & 377 & Gravity & 0 to 3.4 & Langton et al. (2008) \\
\hline CD 38-02 & -14.93 & -77.07 & 2525 & Piston & 1.6 to 265.9 & Ganeshram et al. (2000) \\
\hline CD 38-17 & -1.60 & -90.43 & 2590 & Piston & 0.7 to 38 & Pichevin (unpublished data) \\
\hline CH07-98 GGC-19 & 36.87 & -74.57 & 1049 & Piston & & Altabet (2007) \\
\hline CR-2 & 14.90 & 74.00 & 45 & Gravity & 0 to 0.7 & Agnihotri et al. (2008b) \\
\hline DR-13 & 53.16 & 177.32 & 3930 & Piston & 1.4 to 28.1 & Nakatsuka et al. (1995b) \\
\hline DR-16 & 54.50 & -176.04 & 3750 & Piston & 2.2 to 59.3 & Nakatsuka et al. (1995b) \\
\hline DSDP 41-367 & 12.49 & -20.05 & 4748 & Drilling & & Rau et al. (1987) \\
\hline DSDP 75-530 & -19.19 & 9.39 & 4629 & Drilling & & Rau et al. (1987) \\
\hline DSDP 93-603 & 35.49 & -70.03 & 4633 & Drilling & & Rau et al. (1987) \\
\hline E11-2 & -56.05 & -115.07 & 3094 & Piston & 9.7 to 39.1 & Robinson et al. (2005) \\
\hline FR-03/96 GC-4 & -12.29 & 121.93 & 2069 & Gravity & & Müller and Opdyke (2000) \\
\hline FR-03/96 GC-5 & -12.37 & 122.20 & 1462 & Gravity & & Müller and Opdyke (2000) \\
\hline GeoB 1008 & -6.58 & 10.32 & 3124 & Gravity & 0.4 to 183 & Holmes et al. (1997) \\
\hline GeoB 1016 & -11.77 & 11.68 & 3411 & Gravity & 1.2 to 302.6 & Holmes et al. (1997) \\
\hline GeoB 3910 & -4.25 & -36.35 & 2362 & Gravity & 11.2 to 19.6 & Dupont et al. (2008) \\
\hline GeoB 3911 & -4.61 & -36.64 & 828 & Gravity & & Jennerjahn et al. (2004) \\
\hline GeoB 3912 & -3.67 & -37.72 & 772 & Gravity & & Jennerjahn et al. (2004) \\
\hline GeoB 4216 & 30.63 & -12.40 & 2324 & Gravity & 2 to 254.3 & Freudenthal et al. (2002) \\
\hline GeoB 4223 & 29.02 & -12.47 & 775 & Gravity & 1 to 88.4 & Freudenthal et al. (2002) \\
\hline GeoB 4234 & 28.89 & -13.23 & 1360 & Multi & & Freudenthal et al. (2001) \\
\hline GeoB 4240 & 28.89 & -13.23 & 1358 & Gravity & 2.5 to 136 & Freudenthal et al. (2002) \\
\hline GeoB 4501 & -22.58 & 14.17 & 97 & Multi & & Struck et al. (2002) \\
\hline GeoB 4502 & -23.14 & 13.17 & 370 & Multi & & Struck et al. (2002) \\
\hline GeoB 7139 & -30.20 & -71.98 & 3269 & Gravity & 0.8 to 70.1 & De Pol-Holz et al. (2007) \\
\hline GeoB 8903 & 38.63 & -9.51 & 102 & Gravity & 0 to 3.1 & Alt-Epping et al. (2009) \\
\hline GGC27 & 49.60 & 150.18 & 995 & Gravity & 0.9 to 154.9 & Brunelle et al. (2010) \\
\hline HLY 0202 JPC17 & 53.93 & 178.70 & 2209 & Piston & 0.8 to 119 & Brunelle et al. (2007) \\
\hline JPC-22 & 28.25 & -74.41 & 4712 & Piston & & Altabet et al. (2005) \\
\hline JT96-09 & 48.90 & -126.88 & 920 & Piston & 0.1 to 16 & McKay et al. (2004) \\
\hline KC01B & 36.25 & 17.74 & 3643 & Gravity & & Struck et al. (2001) \\
\hline KH-92-1 3bPC & 8.02 & 139.64 & 2831 & Piston & & Nakatsuka et al. (1995a) \\
\hline КH-92-1 5bPC & 3.54 & 141.86 & 2279 & Piston & & Nakatsuka et al. (1995a) \\
\hline MD 76-131 & 15.53 & 72.57 & 1230 & Piston & 4 to 81 & Ganeshram et al. (2000) \\
\hline MD 84-527 & -43.83 & 51.32 & 3269 & Piston & 2.1 to 38.4 & Francois et al. (1993) \\
\hline MD 84-552 & -54.92 & 73.83 & 1780 & Piston & 0.4 to 87.8 & Francois et al. (1997) \\
\hline MD 84-641 & 33.03 & 32.63 & 1375 & Piston & 3.9 to 465.3 & Calvert et al. (1992) \\
\hline MD 88-773 & -52.92 & 109.87 & 2460 & Piston & 0.4 to 29.2 & Francois et al. (1997) \\
\hline MD 96-2080 & -36.27 & 19.48 & 2488 & Piston & 1 to 857 & Rau et al. (2002) \\
\hline MD 96-2084 & -31.74 & 15.52 & 1408 & Piston & 0 to 838 & $\operatorname{Rau}(2002)$ \\
\hline MD 96-2086 & -25.81 & 12.13 & 3606 & Piston & 10 to 296.4 & Pichevin et al. (2005) \\
\hline MD 96-2087 & -25.60 & 13.38 & 1029 & Piston & 6.2 to 299.8 & Pichevin et al. (2005) \\
\hline MD 96-2098 & -25.59 & 12.63 & 2909 & Piston & 6 to 193.3 & Pichevin et al. (2005) \\
\hline MD 97-2101 & -43.50 & 79.84 & 3145 & Piston & 3.4 to 57.9 & Crosta (unpublished data) \\
\hline MD 97-2146 & 20.12 & 117.38 & 1727 & Piston & 0 to 36.9 & Kienast et al. (2005) \\
\hline MD 98-2162 & -4.68 & 117.90 & 1855 & Piston & 0.8 to 24 & M. Kienast (unpublished data) \\
\hline MD 98-2177 & 1.40 & 119.67 & 968 & Piston & 0 to 48.8 & M. Kienast (unpublished data) \\
\hline MD 98-2181 & 6.30 & 125.82 & 2114 & Piston & 0 to 9.9 & Kienast et al. (2008) \\
\hline MD 01-2386 & 1.13 & 129.79 & 2816 & Piston & 0 to 145.9 & Jia and Li (2011) \\
\hline
\end{tabular}


Table 1. Continued.

\begin{tabular}{|c|c|c|c|c|c|c|}
\hline Core name & Latitude & Longitude & Depth (m) & Core type & Timespan (ka) & Reference \\
\hline MD 01-2392 & 9.85 & 110.21 & 1966 & Piston & 0.1 to 151 & Jia and Li (2011) \\
\hline MD 01-2403 & 25.07 & 123.28 & 1420 & Piston & 0.2 to 25.2 & Kao et al. (2008) \\
\hline MD 01-2404 & 26.65 & 125.81 & 1397 & Piston & 0.7 to 25.1 & Kao et al. (2008) \\
\hline MD 01-2416 & 51.27 & 167.73 & 2317 & Piston & 5.9 to 450.2 & Galbraith et al. (2008b) \\
\hline MD 02-2496 & 48.97 & -127.04 & 1243 & Piston & 2.3 to 50.4 & Chang et al. (2008) \\
\hline MD 02-2519 & 22.52 & -106.65 & 955 & Piston & 2.4 to 112.4 & Arellano-Torres (2010) \\
\hline MD 02-2520 & 15.67 & -95.30 & 719 & Piston & 0.5 to 48.8 & Pichevin et al. (2010) \\
\hline MD 02-2524 & 12.01 & -87.91 & 863 & Piston & 3.7 to 77.2 & Pichevin et al. (2010) \\
\hline MD 02-2550 & 26.95 & -91.35 & 2249 & Box & 0.5 to 24.1 & Meckler et al. (2011) \\
\hline MD 03-2601 & -66.05 & 138.56 & 746 & Piston & 1 to 11 & Denis et al. (2009) \\
\hline MD 03-2603 & -64.29 & 139.38 & 3290 & Piston & 0 to 565.3 & Presti et al. (2011) \\
\hline MD 03-2621 & 10.68 & -64.97 & 850 & Piston & 0.7 to 22.7 & Meckler et al. (2007) \\
\hline MD 04-2876 & 24.84 & 64.01 & 828 & Piston & 0.1 to 49.5 & Pichevin et al. (2007) \\
\hline MD 06-3067 & 6.52 & 126.50 & 1574 & Piston & 3.5 to 9.9 & Kienast et al. (2008) \\
\hline MD 06-3075 & 6.48 & 125.87 & 1878 & Piston & 0.1 to 9.4 & Kienast et al. (2008) \\
\hline ME0005A-03JC & 15.65 & -95.28 & 740 & Piston & 1.7 to 23 & Thunell and Kepple (2004) \\
\hline ME0005A-11PC & 15.71 & -95.29 & 574 & Piston & 1.8 to 28.6 & Hendy and Pedersen (2006) \\
\hline ME0005A-24JC & 0.02 & -86.46 & 2941 & Gravity & 1.6 to 133.4 & Dubois et al. (2011) \\
\hline ME0005A-27JC & -1.85 & -82.79 & 2203 & Gravity & 0.9 to 150.7 & Dubois et al. (2011) \\
\hline ME33-EAST & 15.59 & 68.58 & 3820 & Gravity & 1.9 to 132.9 & Möbius et al. (2011) \\
\hline ME33-NAST & 20.00 & 65.68 & 3167 & Gravity & 0.1 to 132.8 & Suthhof et al. (2001) \\
\hline MR98-05-3 & 50.00 & 164.98 & 5507 & Piston & 4.6 to 143.6 & Shigemitsu et al. (2008) \\
\hline MR06-04 PC24A & 60.26 & -179.42 & 852 & Piston & 12.7 to 71.5 & Kim et al. (2011) \\
\hline MW8708-PC2 & -15.10 & -75.70 & 270 & Piston & 2.1 to 8.4 & $\begin{array}{l}\text { Agnihotri et al. (2006); } \\
\text { Chazen et al. (2009) }\end{array}$ \\
\hline NAM1 & -22.67 & 14.00 & 125 & Box & 0 to 2.9 & Struck et al. (2002) \\
\hline NH8P & 22.39 & -107.08 & 1018 & Piston & 1.6 to 50.1 & Ganeshram et al. (1995) \\
\hline NH15P & 22.68 & -106.48 & 420 & Piston & 1 to 112 & Ganeshram et al. (2000) \\
\hline $\mathrm{NH} 22 \mathrm{P}$ & 22.52 & -106.52 & 2025 & Piston & 3.1 to 139 & Ganeshram et al. (1995) \\
\hline NIOP 455 & 23.55 & 65.95 & 1002 & Piston & 9 to 116.7 & Reichart et al. (1998) \\
\hline NIOP 464 & 22.25 & 63.58 & 1470 & Piston & 10.1 to 226 & Reichart et al. (1998) \\
\hline NIOP 905 & 10.01 & 51.01 & 1586 & Piston & 0.6 to 87.8 & Ivanochko et al. (2005) \\
\hline ODP 722 & 16.62 & 59.80 & 2028 & Advanced Piston & 21.7 to 949.3 & Altabet et al. (1999) \\
\hline ODP 723 & 18.05 & 57.61 & 808 & Advanced Piston & & Higginson et al. (2004) \\
\hline ODP 882 & 50.35 & 167.58 & 3244 & Advanced Piston & 10.7 to 147.1 & $\begin{array}{l}\text { Sigman et al. (2004); } \\
\text { Galbraith et al. (2008b) }\end{array}$ \\
\hline ODP 887 & 54.37 & -148.45 & 3647 & Advanced Piston & 0.3 to 739.5 & Galbraith et al. (2004) \\
\hline ODP 893 & 34.29 & -120.04 & 577 & Advanced Piston & 0 to 48.6 & Emmer and Thunell (2000) \\
\hline ODP 964 & 36.26 & 17.75 & 3770 & Advanced Piston & 184 to 273 & Higgins et al. (2010) \\
\hline ODP 967 & 34.07 & 32.73 & 2550 & Advanced Piston & & Struck et al. (2001) \\
\hline ODP 969A & 33.84 & 24.88 & 2212 & Advanced Piston & 111 to 144 & Higgins et al. (2010) \\
\hline ODP 969E & 34.23 & 29.87 & 2400 & Advanced Piston & & Milder et al. (1999) \\
\hline ODP 974 & 40.36 & 12.14 & 3454 & Advanced Piston & & Milder et al. (1999) \\
\hline ODP 999 & 12.75 & -78.73 & 2827 & Advanced Piston & 4.2 to 30.9 & Ren et al. (2009) \\
\hline ODP 1002 & 10.71 & -65.17 & 893 & Advanced Piston & 0.8 to 579.4 & $\begin{array}{l}\text { Haug et al. (1998); } \\
\text { Meckler et al. (2007) }\end{array}$ \\
\hline ODP 1012 & 32.28 & -118.40 & 1772 & Advanced Piston & 7.6 to 4114.3 & Liu et al. (2008) \\
\hline ODP 1017 & 34.54 & -121.27 & 955 & Advanced Piston & 0 to 74.8 & $\begin{array}{l}\text { Ganeshram et al. (2000); } \\
\text { Hendy et al. (2004) }\end{array}$ \\
\hline ODP 1019 & 41.68 & -124.93 & 977 & Advanced Piston & 7.3 to 24.2 & Ivanochko and Pedersen (2004) \\
\hline ODP 1033 & 48.59 & -123.50 & 345 & Advanced Piston & 0 to 11.9 & Calvert et al. (2001) \\
\hline ODP 1078 & -11.92 & 13.40 & 426 & Advanced Piston & 0 to 48.2 & Galbraith (unpublished data) \\
\hline ODP 1082 & -21.10 & 11.82 & 1280 & Advanced Piston & 376 to 3480 & $\begin{array}{l}\text { Robinson and Meyers (2002); } \\
\text { Etourneau et al. (2009) }\end{array}$ \\
\hline ODP 1084 & -25.52 & 13.02 & 1992 & Advanced Piston & 1945 to 2308 & Robinson and Meyers (2002) \\
\hline ODP 1090 & -42.91 & 8.90 & 3702 & Advanced Piston & 1448.2 to 3486.5 & Etourneau et al. (2009) \\
\hline
\end{tabular}


Table 1. Continued.

\begin{tabular}{|c|c|c|c|c|c|c|}
\hline Core name & Latitude & Longitude & Depth (m) & Core type & Timespan (ka) & Reference \\
\hline ODP 1096 & -67.57 & -76.97 & 3152 & Advanced Piston & & Sigman et al. (2004) \\
\hline ODP 1144 & 20.05 & 117.42 & 2037 & Advanced Piston & 0.1 to 145 & Higginson et al. (2003) \\
\hline ODP 1207 & 37.79 & 162.75 & 3101 & Drilling & & Dumitrescu and Brassell (2006) \\
\hline ODP 1228 & -11.06 & -78.08 & 273 & Advanced Piston & 0.9 to 14.6 & Agnihotri et al. (2006) \\
\hline ODP 1233 & -41.00 & -74.45 & 838 & Advanced Piston & 0 to 50.6 & Martinez et al. (2006) \\
\hline ODP 1234 & -36.22 & -73.68 & 1015 & Advanced Piston & 1.6 to 82.2 & Robinson et al. (2007) \\
\hline ODP 1239 & -0.67 & -82.08 & 1414 & Advanced Piston & 0.9 to 81.7 & Etourneau (unpublished data) \\
\hline ODP 1240 & 0.02 & -86.46 & 2921 & Advanced Piston & 2.1 to 31.8 & Pichevin et al. (2009) \\
\hline ODP 1240 & 0.02 & -86.46 & 2921 & Advanced Piston & 3.9 to 41.4 & Robinson et al. (2009) \\
\hline ODP 1242 & 7.86 & -83.61 & 1364 & Advanced Piston & 1 to 30.1 & Robinson et al. (2009) \\
\hline P7GC & 2.60 & -84.00 & 3085 & Gravity & 7 to 29.1 & Farrell et al. (1995) \\
\hline PC13 & 49.72 & 168.30 & 2393 & Piston & 4 to 156.2 & Brunelle et al. (2010) \\
\hline PRCK-3-2 & 38.54 & -76.43 & 24 & Piston & & Bratton et al. (2003) \\
\hline PS2163 & 86.24 & 59.22 & 3040 & Multi & 0.8 to 42.3 & Schubert et al. (2001) \\
\hline PS2170 & 87.60 & 60.90 & 4083 & Multi & 0.7 to 41.8 & Schubert et al. (2001) \\
\hline PS2178 & 88.02 & 159.59 & 4008 & Multi & 1.9 to 132.3 & Schubert et al. (2001) \\
\hline PS2185 & 87.50 & 144.48 & 1051 & Multi & 2.2 to 55.5 & Schubert et al. (2001) \\
\hline PTMC-3-1 & 38.03 & -76.22 & 23 & Piston & & Bratton et al. (2003) \\
\hline PX98-2 & 38.33 & -76.38 & 9 & Piston & & Bratton et al. (2003) \\
\hline $\mathrm{RC} 13-259$ & -53.88 & -4.93 & 2677 & Piston & & Brzezinski et al. (2002) \\
\hline $\mathrm{RC} 27-14$ & 18.25 & 57.66 & 596 & Piston & 4.1 to 63.3 & Altabet et al. (2002) \\
\hline $\mathrm{RC} 27-23$ & 17.99 & 57.59 & 820 & Piston & 0.1 to 63.6 & Altabet et al. (2002) \\
\hline $\mathrm{RC} 27-24$ & 17.72 & 57.82 & 1416 & Piston & 1 to 145 & Altabet et al. (1995) \\
\hline RC27-61 & 16.66 & 59.52 & 1893 & Piston & 3.7 to 370.6 & Altabet et al. (1995) \\
\hline RD98-P2 & 38.89 & -76.39 & 27 & Piston & & Bratton et al. (2003) \\
\hline RR98-6 & 38.88 & -76.45 & 8 & Piston & & Bratton et al. (2003) \\
\hline $\mathrm{SC}-8$ & 5.01 & 156.14 & 3604 & Box & & Nakatsuka et al. (1995a) \\
\hline SK117-GC08 & 15.48 & 72.85 & 2500 & Gravity & 0.9 to 99.6 & Banakar et al. (2005) \\
\hline SK177/11 & 8.20 & 76.47 & 776 & Gravity & 0 to 34.4 & Kao (unpublished data) \\
\hline SK126/39 & 12.63 & 73.33 & 1940 & Gravity & 0 to 72.8 & Kessarkar et al. (2010) \\
\hline SL226620 & -22.76 & 14.31 & 81 & Gravity & 0.6 to 5.6 & Emeis et al. (2009) \\
\hline SO42-74KL & 14.32 & 57.35 & 3212 & Piston & 0.3 to 23.8 & Suthhof et al. (2001) \\
\hline SO90-111KL & 23.10 & 66.48 & 775 & Piston & 5.3 to 65.5 & Suthhof et al. (2001) \\
\hline SO95 GIK17924-3 & 19.41 & 118.85 & 3438 & Gravity & 0 to 140 & Kienast (2000) \\
\hline SO95 GIK17940-2 & 20.12 & 117.38 & 1727 & Gravity & 0 to 39.7 & Kienast (2000) \\
\hline SO95 GIK17954-2 & 14.76 & 111.53 & 1517 & Gravity & 0.4 to 220.5 & Kienast (2000) \\
\hline SO95 GIK17961-2 & 8.51 & 112.33 & 1795 & Gravity & 1.8 to 142.3 & Kienast (2000) \\
\hline SO95 GIK17964-2 & 6.16 & 112.21 & 1556 & Piston & 14.7 to 33.8 & Kienast (2000) \\
\hline SO95 GIK17964-3 & 6.16 & 112.21 & 1556 & Gravity & 0.3 to 23.2 & Kienast (2000) \\
\hline SO115 GIK18284-3 & 5.54 & 110.54 & 226 & Gravity & 3.6 to 16.6 & Kienast (2000) \\
\hline SS3268G5 & 12.50 & 74.20 & 600 & Gravity & 0.1 to 10.4 & Agnihotri et al. (2003) \\
\hline SS4018G & 13.21 & 53.26 & 2830 & Gravity & 0 to 19 & Tiwari et al. (2010) \\
\hline St-11 & 57.05 & -176.96 & 3650 & Piston & 1.2 to 22.3 & Nakatsuka et al. (1995b) \\
\hline SU90-09 & 43.08 & -31.08 & 3375 & Piston & 2.7 to 56 & Huon et al. (2002) \\
\hline SU94-11K & 21.48 & -17.95 & 1200 & Piston & & Bertrand et al. (2000) \\
\hline SU94-20bK & 25.03 & -16.65 & 1445 & Piston & 2.5 to 143.8 & Martinez et al. (2000) \\
\hline TR163-19 & 2.26 & -90.95 & 2348 & Piston & 4.4 to 99.9 & Dubois et al. (2011) \\
\hline TR163-22 & 0.52 & -92.40 & 2830 & Piston & 3 to 40.4 & Robinson et al. (2009) \\
\hline TR163-22 & 0.52 & -92.40 & 2830 & Piston & 3.7 to 134.7 & $\begin{array}{l}\text { Dubois and M. Kienast } \\
\text { (unpublished data) }\end{array}$ \\
\hline TR163-31 & -3.62 & -83.97 & 3205 & Piston & 5.1 to 244.3 & Dubois et al. (2011) \\
\hline TT199-5-GC26 & 2.70 & -86.00 & & Gravity & 0 to 175 & Farrell et al. (1995) \\
\hline TTN013-PC72 & 0.11 & -139.40 & 4298 & Piston & 2.7 to 599.4 & Altabet (2001) \\
\hline V34-101 & 17.49 & 67.42 & 3038 & Piston & & Altabet et al. (1999) \\
\hline VNTR01-8PC & 0.03 & -110.48 & 3791 & Piston & & M. Kienast (unpublished data) \\
\hline VNTR01-13GC & -3.09 & -90.82 & 3304 & Gravity & & Farrell et al. (1995) \\
\hline W7706-37 & -13.63 & -76.85 & 370 & Gravity & 13.8 to 20 & Higginson and Altabet (2004) \\
\hline
\end{tabular}


Table 1. Continued.

\begin{tabular}{|c|c|c|c|c|c|c|}
\hline Core name & Latitude & Longitude & Depth (m) & Core type & Timespan (ka) & Reference \\
\hline W7706-40 & -11.25 & -77.97 & 186 & Gravity & 0.3 to 4.5 & $\begin{array}{l}\text { Higginson and Altabet (2004); } \\
\text { Agnihotri et al. (2008a) }\end{array}$ \\
\hline W7706-41 & -11.35 & -78.12 & 410 & Gravity & 10.1 to 18.6 & Higginson and Altabet (2004) \\
\hline W7706-77 & -5.58 & -81.04 & 366 & Gravity & & Altabet (2007) \\
\hline W8709-1 BC & 41.54 & -131.96 & 3680 & Box & 0.4 to 36.9 & $\begin{array}{l}\text { S. Kienast and Calvert } \\
\text { (unpublished data) }\end{array}$ \\
\hline W8709-2 PC & 41.35 & -132.00 & 3684 & Piston & 0.4 to 1190.7 & $\begin{array}{l}\text { S. Kienast and Calvert } \\
\text { (unpublished data) }\end{array}$ \\
\hline W8709-8 TC/PC & 42.26 & -127.68 & 3111 & Trigger+Piston & 0.4 to 106.5 & Kienast et al. (2002) \\
\hline W8709-13 PC & 42.12 & -125.75 & 2712 & Piston & 6.3 to 67.8 & Kienast et al. (2002) \\
\hline Y71-6-12 & -16.45 & -77.57 & 2734 & Piston & & S. Kienast (unpublished data) \\
\hline
\end{tabular}

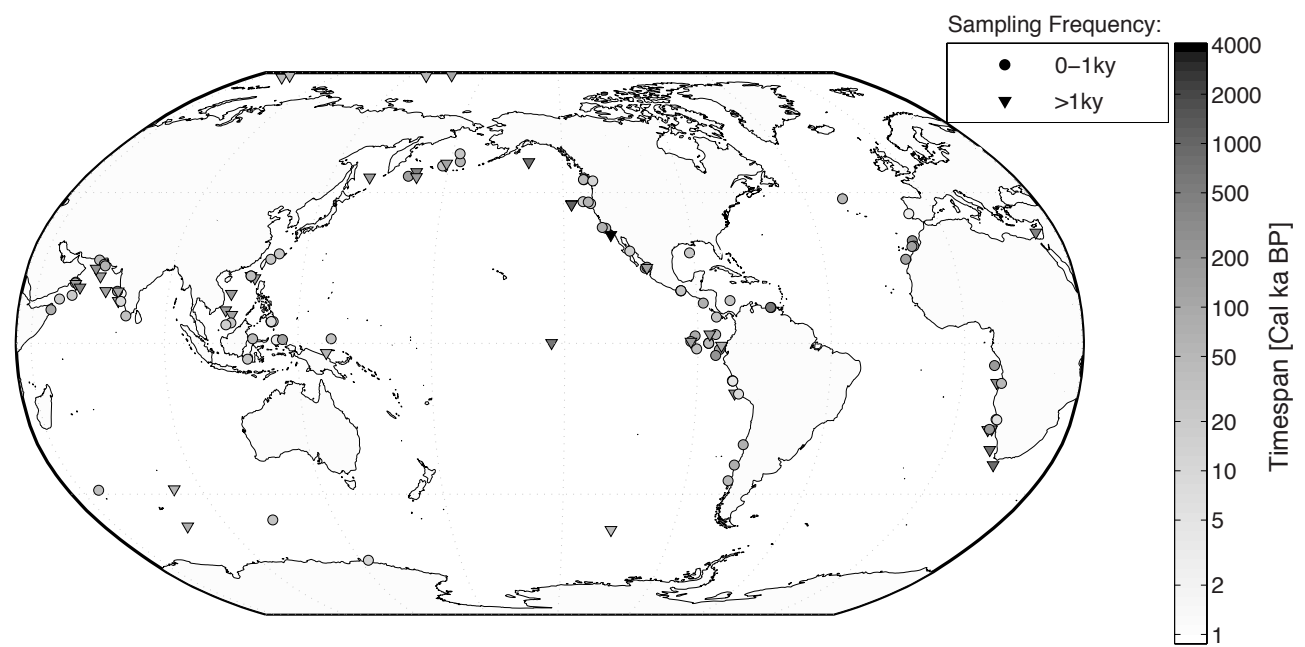

Fig. 3. Locations of cores with a $\delta^{15} \mathrm{~N}$ record versus age. Each symbol represents a core site. The $\delta^{15} \mathrm{~N}$ records of each site differ both in their time ranges and in the resolution of their data. The shaded symbols indicate the timespan (Cal ka BP). We categorized records with high (circles) and low temporal resolution (triangles). High temporal resolution is considered to be an average sampling frequency of at least one data point every ky, whereas low resolution is everything longer than this threshold.

\subsection{Consistency between seafloor and neighbouring subseafloor sediments}

As shown above, the $\delta^{15} \mathrm{~N}$ of neighbouring seafloor sediment samples is consistent within a $100 \mathrm{~km}$ radius for most of the oceans, suggesting that local variability of sedimentary environments does not usually compromise the nitrogen isotopic signal on the modern seafloor. However, it is possible that this seafloor material undergoes significant alteration during and immediately after burial, while still within the highly dynamic sediment horizon less than $20 \mathrm{~cm}$ beneath the sediment-water interface. In order to examine this, we follow the logic of Freudenthal et al. (2001), who argued that post-depositional alteration should be apparent as a downcore gradient in the sediments deposited during the otherwise stable Holocene. Given that the age of core-tops and the precision of age control is highly variable among our database, we averaged all $\delta^{15} \mathrm{~N}$ of late Holocene age ( $\left.\mathrm{LH}, 0-5 \mathrm{ka} \mathrm{BP}\right)$ for each available record. In general, one would expect the average LH $\delta^{15} \mathrm{~N}$ of a sediment record to be about the same as the $\delta^{15} \mathrm{~N}$ of the surrounding surface sediments, assuming that the $\delta^{15} \mathrm{~N}$ of sinking organic nitrogen has been constant over this time period (Thunell et al., 2004).

To test this hypothesis, we examine the correlation between the average LH subseafloor $\delta^{15} \mathrm{~N}$ and the average $\delta^{15} \mathrm{~N}$ of neighbouring seafloor samples within a radius of $100 \mathrm{~km}$. First, we examine the correlation between LH and seafloor sediments within the eastern equatorial Pacific, where largeamplitude $\delta^{15} \mathrm{~N}$ gradients are found together with relatively good coverage of both the seafloor and subseafloor. We average the core-top $\delta^{15} \mathrm{~N}$ that falls within a $100 \mathrm{~km}$ radius of a chosen core site (see large circles, Fig. 5) and plot them against the LH average of that site (Fig. 6a). As shown, the LH and seafloor averages correlate well $(r=0.78)$ and show the same trend of lower $\delta^{15} \mathrm{~N}$ along the equator and coastline, and increased $\delta^{15} \mathrm{~N}$ toward higher latitudes (Fig. 5). 

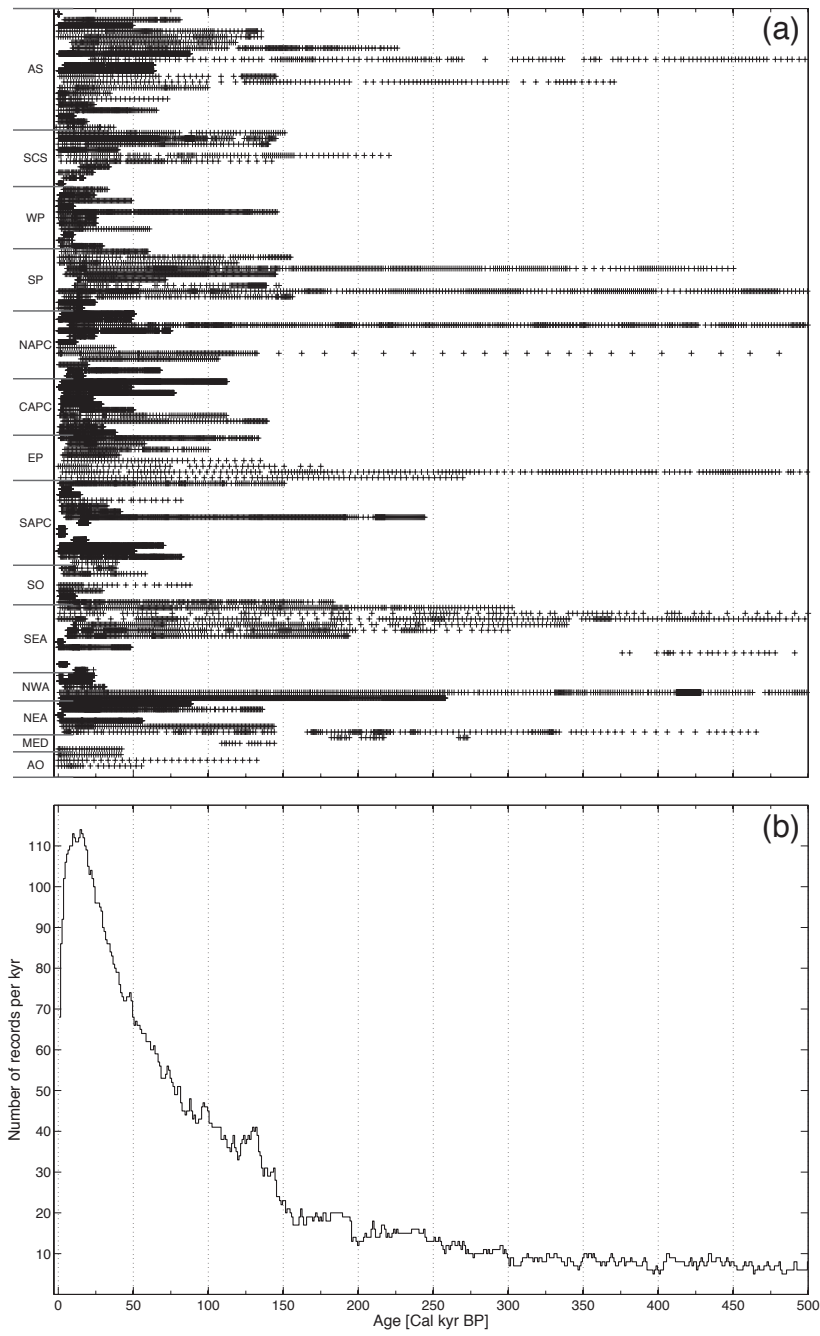

Fig. 4. Data point distribution through the last $500 \mathrm{ka}$. (a) Each record is plotted horizontally, and each black cross represents a data point. Records are grouped by major oceanic regions: Arabian Sea (AS), South China Sea (SCS), west Pacific (WP), subarctic Pacific (SP), North American Pacific coast (NAPC), Central American Pacific coast (CAPC), equatorial Pacific (EP), South American Pacific coast (SAPC), Southern Ocean (SO), southeast Atlantic (SEA), northwest Atlantic including Caribbean Sea and Gulf of Mexico (NWA), northeast Atlantic (NEA), Mediterranean Sea (MED) and Arctic Ocean (AO). (b) Time series of the number of records per ky through the last $500 \mathrm{ka}$.

Interestingly, the line of best fit is shifted, nearly parallel to the $1: 1$ line, suggesting a small, uniform $\delta^{15} \mathrm{~N}$ enrichment from LH to seafloor values. We used a non-parametric bootstrap resampling of the data to test the consistency of the regression coefficients; this showed that the y-intercept has much higher uncertainty than the slope. We repeated this exercise for the Arabian Sea, and found similar results of $r=0.81$ (not shown).

We then extended this analysis to the global dataset (Fig. 6b). The correlation for the global ocean is even

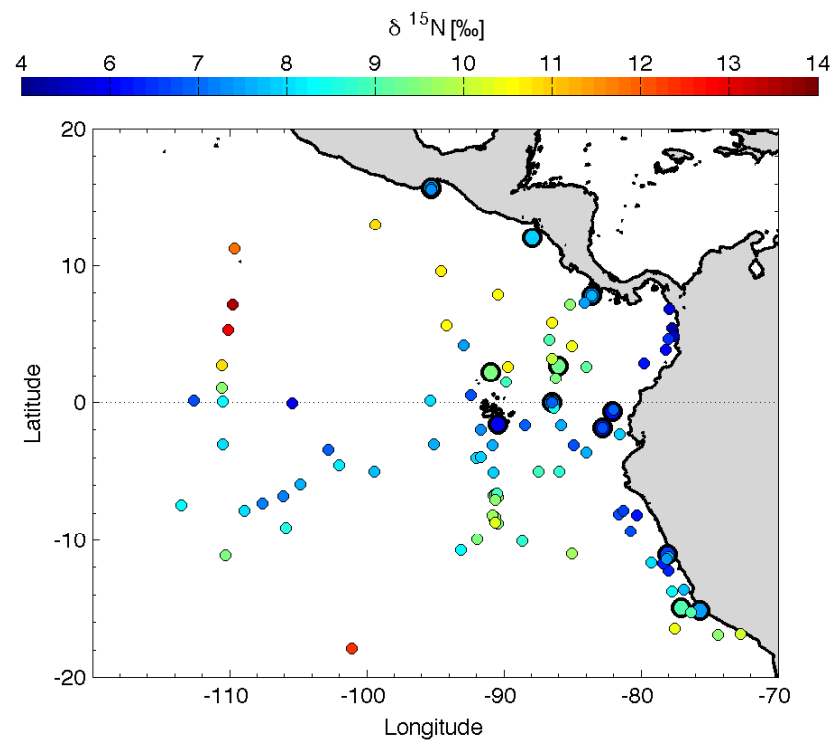

Fig. 5. Locations of sediment core sites (large circles) and surface samples (smaller circles) in the eastern equatorial Pacific. The large circles approximately encompass the spatial range of a $100 \mathrm{~km}$ radius. All surface samples that fall within that range are averaged and compared to the LH average of the core site.

stronger than for the eastern equatorial Pacific and Arabian Sea $\left(r=0.93, R_{1: 1}{ }^{2}=0.82-0.84\right)$, with little deviation from the $1: 1$ line. There are a number of outliers, but these are either from regions with large variability between neighbouring seafloor measurements (large vertical whiskers, Fig. 6b), or with only one neighbour (no vertical whiskers). This correlation is highly encouraging for the use of bulk sedimentary nitrogen isotope measurements as a record of past changes in the sinking flux of organic nitrogen.

Despite the small magnitude of the discrepancies between seafloor and shallow subseafloor sediments, it is worthwhile considering their occurrence. The reasoning of Freudenthal et al. (2001) would predict that any discrepancies should represent diagenetic alterations. Surprisingly, the relationship between surface and LH values, $\delta^{15} \mathrm{~N}_{\text {seafloor }}-\delta^{15} \mathrm{~N}_{\mathrm{LH}}$, shows some spatial coherence, with clear contrasts between oceanic regions (Fig. 7). The $\delta^{15} \mathrm{~N}_{\text {seafloor }}-\delta^{15} \mathrm{~N}_{\mathrm{LH}}$ is consistently negative on the western coast of Africa, consistent with observations made by Freudenthal et al. (2001). However, the picture is reversed along the western coasts of South and North America, where no sites show significant negative $\delta^{15} \mathrm{~N}_{\text {seafloor }}-\delta^{15} \mathrm{~N}_{\mathrm{LH}}$. Elsewhere in the Pacific and Indian oceans, the changes between LH and surface $\delta^{15} \mathrm{~N}$ are generally small or mixed.

We can conceive of two possibilities to explain these contrasts, one being that post-depositional alteration of $\delta^{15} \mathrm{~N}$ varies between basins, due to changes in sediment characteristics, organic matter composition, or seafloor biota. Given that similar seafloor environments show opposite patterns 

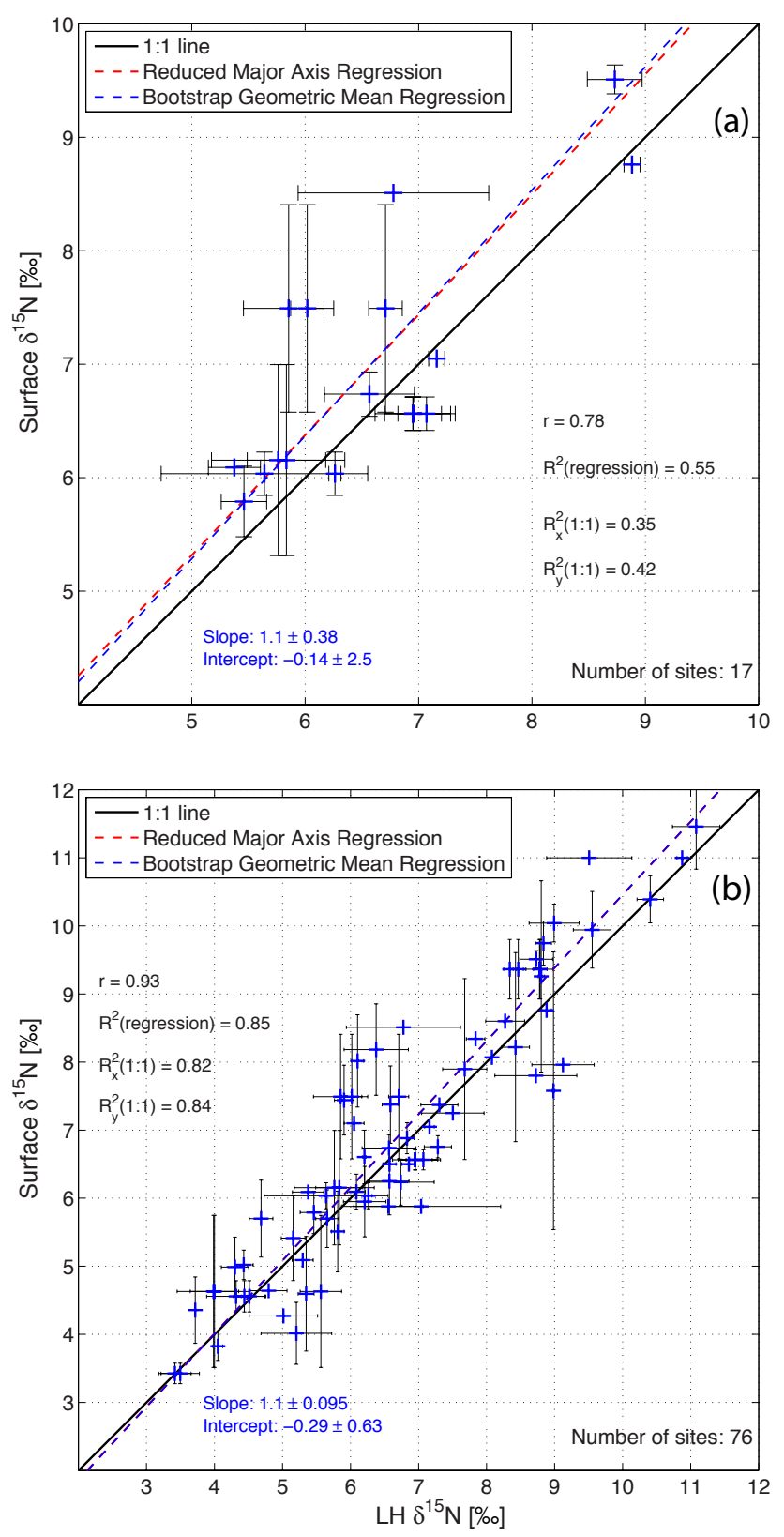

Fig. 6. LH $\delta^{15} \mathrm{~N}$ average compared with surface $\delta^{15} \mathrm{~N}$ within $100 \mathrm{~km}$ for (a) the eastern equatorial Pacific and (b) for all available records. The horizontal whiskers show the temporal variance of the LH average, and the vertical whiskers indicate the spatial variance of the surface sample average.

(for example, the Benguela and Peruvian upwellings), while different environments within the same region show similar patterns (for example, Angola and the Mediterranean), this explanation seems unlikely. The second, more likely explanation is that the $\delta^{15} \mathrm{~N}$ of sinking organic matter changed significantly over the late Holocene. If this is true, it implies that the fidelity with which seafloor $\delta^{15} \mathrm{~N}$ is transferred into the sedimentary record is somewhat better than would be in- dicated by our seafloor-LH comparison (Fig. 6), since the assumption of temporal invariance is incorrect.

The sense of change between the LH and seafloor sediments, with decreasing $\delta^{15} \mathrm{~N}$ in the Atlantic and increasing $\delta^{15} \mathrm{~N}$ in the Pacific, would be consistent with an increase of water column denitrification (dominantly in the Indo-Pacific) and/or an increase of $\mathrm{N}_{2}$ fixation rates (the isotopic imprint of which is stronger in the Atlantic) over this time period. We leave the resolution of this observation to future work.

\subsection{Consistency between young and old sediments}

The final possibility addressed here is that post-depositional alteration makes a significant imprint over longer timescales, e.g., $10^{5} \mathrm{yr}$. In order to test this, we make the assumption that the nitrogen cycle behaved similarly over each of the most recent four glacial-interglacial cycles. This assumption is supported by the similarity of oceanic $\delta^{18} \mathrm{O}$ (Lisiecki and Raymo, 2005) and ice core records (Petit et al., 1999) over this interval. Thus, we would expect that the average $\delta^{15} \mathrm{~N}$ recorded over a full glacial-interglacial cycle should be similar for all four cycles. We test this by averaging all available $\delta^{15} \mathrm{~N}$ measurements within each cycle, defined by the terminations given in Lisiecki and Raymo (2005). Errors in the assignments of the sedimentary depths at which terminations occurred should lead to one cycle's $\delta^{15} \mathrm{~N}$ becoming erroneously high, while the adjacent cycle's would become lower.

The data show consistent averages between cycles for some cores, while others show lower $\delta^{15} \mathrm{~N}$ in older sediments (Fig. 8). In no cases did the older sediments show higher $\delta^{15} \mathrm{~N}$. Although we were not able to find a variable that successfully predicted the magnitude of the $\delta^{15} \mathrm{~N}$ decreases between cycles, the water depth appears to divide the sites into two populations. The shallow sites (arbitrarily defined as water depth $<2000 \mathrm{~m}$ ) show no consistent trend between cycles, as expected from the assumption of stationarity in the global $\mathrm{N}$ cycle over successive glacial-interglacial cycles, and an absence of long-term downcore diagenesis. However, the deep sites show lower $\delta^{15} \mathrm{~N}$ in older sediments. Interestingly, the difference of $\delta^{15} \mathrm{~N}$ between successive glacial cycles becomes smaller in older sediments, with differences $0.5 \pm 0.20 \%$ o between cycles 1 and $2,0.4 \pm 0.17 \%$ o between cycles 2 and 3 , and $0.0 \pm 0.19 \%$ o between cycles 3 and 4 .

The magnitude of this decreasing trend, on the order of $1 \%$, is similar to the standard deviations of the records. If the diagenetic alteration were eliminating the record of past variability, it would be expected to reduce the standard deviations of the records going back in time. In fact, there is no such trend, suggesting that the long-term alteration does not eliminate the primary signal of variability in the export flux. However, given that it does shift the signal by an amount that rivals the original signal, it would be advantageous to quantify the long-term diagenesis if $\delta^{15} \mathrm{~N}$ records of bulk $\mathrm{N}$ from the deep sea are to be used. The similarity among the 


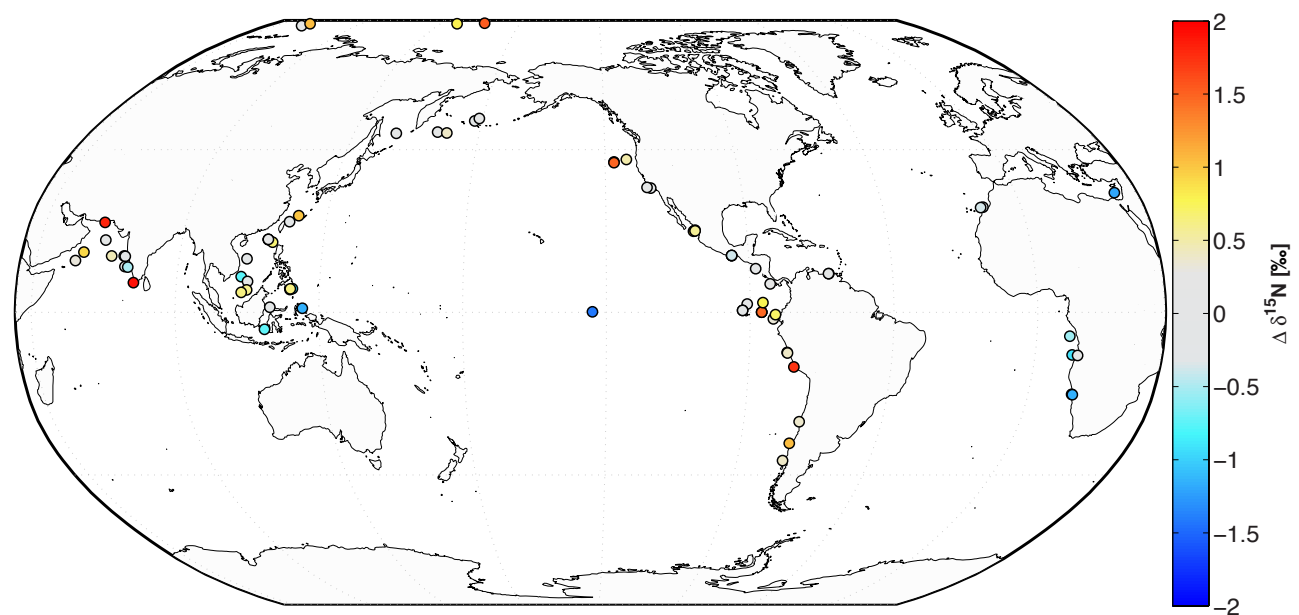

Fig. 7. Difference between surface and LH $\delta^{15} \mathrm{~N}$ averages for available sites. The difference is calculated as $\delta^{15} \mathrm{~N}_{\text {seafloor }}-\delta^{15} \mathrm{~N}_{\mathrm{LH}}$, such that positive values indicate that the average $\delta^{15} \mathrm{~N}$ of the seafloor sediments is higher than that of the late Holocene.

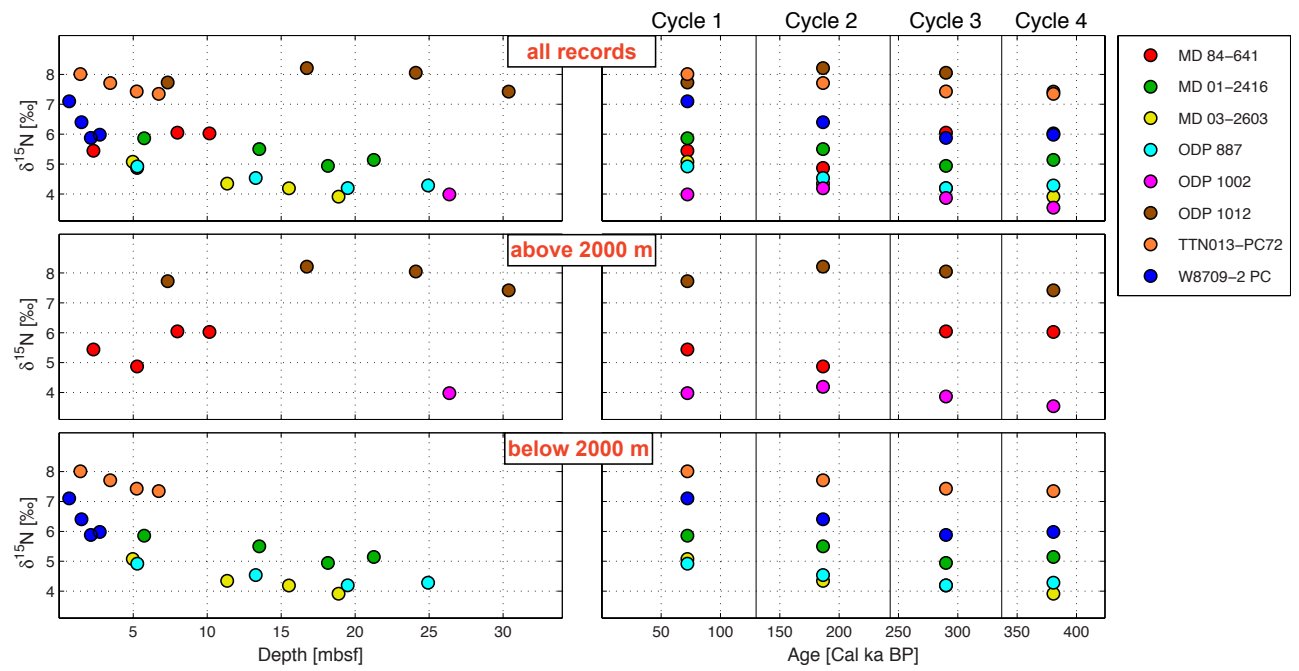

Fig. 8. Plots of $\delta^{15} \mathrm{~N}$ versus depth and age for each of the eight records that span at least four glacial-interglacial cycles (i.e. 14 to $424 \mathrm{ka}$ ). $\delta^{15} \mathrm{~N}$ is binned according to the four glacial-interglacial cycles. The top panels show binned $\delta^{15} \mathrm{~N}$ for all eight records versus depth (left) and versus age (right). The middle panels show only those records from sites shallower than $2000 \mathrm{~m}$ water depth, while the bottom panels only those from sites deeper than $2000 \mathrm{~m}$ water depth.

long-term diagenesis evident in deep-sea records prompts us to seek a general mechanism that might explain it.

\section{Mechanisms of diagenesis}

The available global nitrogen isotopic data clearly show a diagenetic ${ }^{15} \mathrm{~N}$ enrichment of the organic nitrogen in seafloor sediments, relative both to the $\delta^{15} \mathrm{~N}$ of sinking organic matter (e.g. Gaye-Haake et al., 2005; Robinson et al., 2012), and to that expected from an ocean biogeochemical model (Galbraith et al., 2013). Moreover, this enrichment is greater in deeper sediments, which may result from their high porewater oxygen concentrations, slow sediment accumulation rates, or other features, as discussed in detail by Robinson et al. (2012).

It has been argued that the amino acids contained in the resistant biomolecules of bacterial cell walls (such as the structural molecule peptidoglycan) become the dominant amino acids in marine sediments during early diagenesis, on timescales of the order of thousands of years (Pedersen et al., 2001). These amino acids include aspartate, glutamate, and alanine, which are significantly enriched in ${ }^{15} \mathrm{~N}$ among consumers, relative to the substrates (McClelland and Montoya, 2002). It seems reasonable to assume that the loss of other low $\delta^{15} \mathrm{~N}$ amino acids, relative to these resistant amino acids with higher $\delta^{15} \mathrm{~N}$, could be the primary cause behind the increase of $\delta^{15} \mathrm{~N}$ at the seafloor. Subsequently, given sufficient 

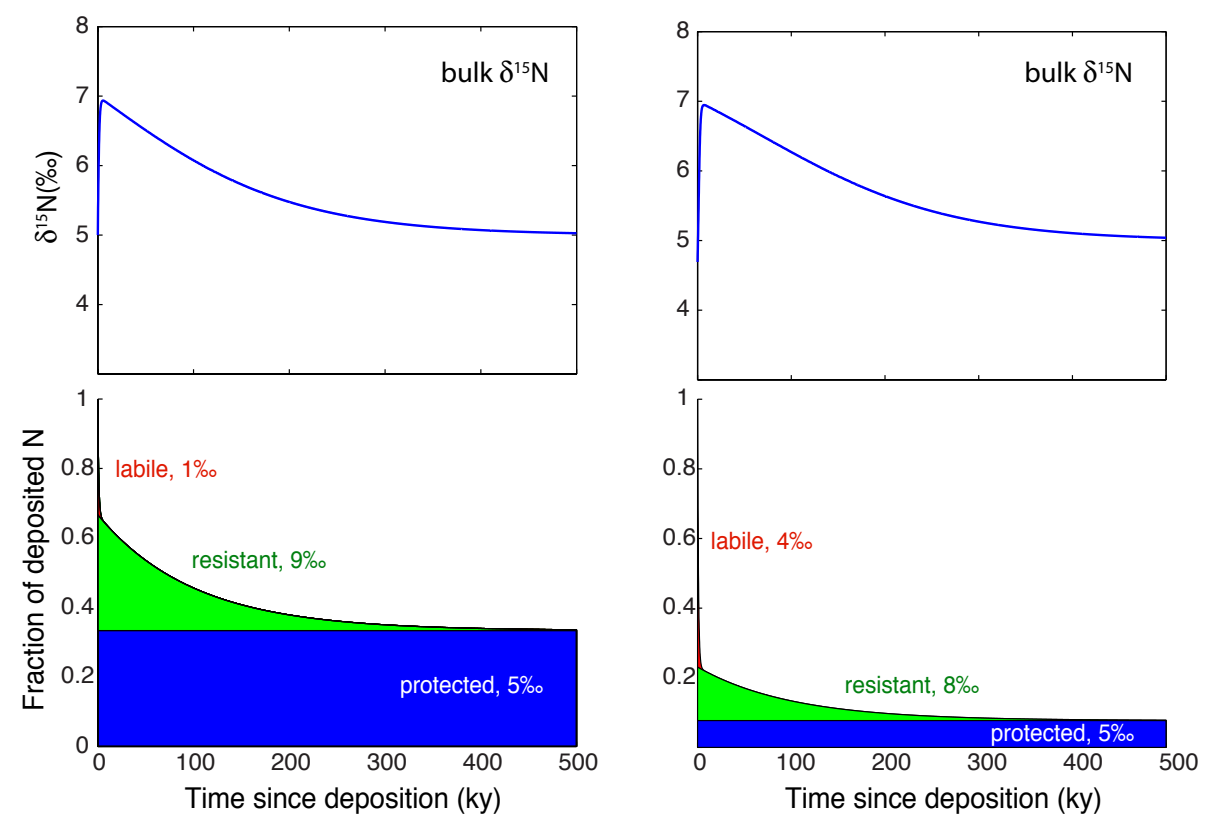

Fig. 9. A conceptual model for long-term $\mathrm{N}$ diagenesis in marine sediment. The top panels show the evolution of bulk $\delta^{15} \mathrm{~N}$ that results from the decay of two exposed organic components, mixed with a protected component, all of different isotopic composition. The left and right panels differ in the starting (deposited) fractions of the three components and their isotopic compositions, as indicated. The model is purely for illustrative purposes, and the parameters were chosen arbitrarily.

time and oxygen, the residual exposed amino acids are likely to be consumed as well, gradually eliminating this effect, until the exposed organic nitrogen is contained exclusively in condensed molecules that resist further degradation.

As the mass of exposed organic nitrogen dwindles, the nitrogen protected by minerals should become more significant, whether sorbed to the surface of clays or protected within the matrices of biogenic opal and calcite. Thus, the bulk isotopic composition should become closer to the isotopic composition of the mineral-protected pools as the protected pools become dominant. In settings where oxygen exposure times are extremely long, such as the deep sea, the extreme loss of exposed organic nitrogen could be expected to make the protected pool more important, which itself would depend on the composition of the sediment. For example, diatom-bound nitrogen would be expected to be important in the opal belts of the equatorial Pacific, subarctic Pacific and Southern Ocean, while calcite-bound nitrogen could be more important in carbonate-rich tropical sediments at shallower depths. Increasing burial depth may cause diagenetic changes in mineral structure, which could liberate protected $\mathrm{N}$ fractions. This liberated $\mathrm{N}$ would be remineralised and could be transported via porewater diffusion, or retained as absorbed $\mathrm{NH}_{4}^{+}$, depending on the redox conditions and mineralogical environment of the sediment.

We suggest an extremely simple conceptual model that can explain aspects of the observations. If we define a labile pool of $\mathrm{N}, \mathrm{N}_{\text {labile }}$, with $\delta^{15} \mathrm{~N}_{\text {labile }}$, a resistant pool of $\mathrm{N}, \mathrm{N}_{\text {resistant }}$, with $\delta^{15} \mathrm{~N}_{\text {resistant }}$, and a protected pool of $\mathrm{N}, \mathrm{N}_{\text {protected }}$ with $\delta^{15} \mathrm{~N}_{\text {protected }}$, we can write the equation

$\delta^{15} \mathrm{~N}_{\text {bulk }}=\frac{\mathrm{N}_{\text {labile }} \delta^{15} \mathrm{~N}_{\text {labile }}+\mathrm{N}_{\text {resistant }} \delta^{15} \mathrm{~N}_{\text {resistant }}+\mathrm{N}_{\text {protected }} \delta^{15} \mathrm{~N}_{\text {protected }}}{\mathrm{N}_{\text {bulk }}}$

If we then assume that the porewaters are open such that dissolved $\mathrm{N}$ is free to leave the system, we can model the loss of the $\mathrm{N}$ pools as first-order processes, similar to the multiG model (Westrich and Berner, 1984), with rate constants $\gamma_{\text {labile }}$ and $\gamma_{\text {resistant }}$ :

$\frac{\mathrm{dN}_{\text {labile }}}{\mathrm{d} t}=-\gamma_{\text {labile }} \mathrm{N}_{\text {labile }}$

and

$\frac{\mathrm{dN}_{\text {resistant }}}{\mathrm{d} t}=-\gamma_{\text {resistant }} \mathrm{N}_{\text {resistant }}$.

We assume, for this very simple illustration, that the protected fraction does not change over time, although in reality it is likely to exchange with the porewater pool to some degree, and could be thought of as including condensed organic phases as well. If we pick decay timescales of $\gamma_{\text {labile }}=1 \mathrm{kyr}^{-1}$ and $\gamma_{\text {resistant }}=0.01 \mathrm{kyr}^{-1}$, the model predicts an evolution of $\delta^{15} \mathrm{~N}_{\text {bulk }}$ and the relative fractions of the three $\mathrm{N}$ components as shown in Fig. 9. Note that the initial values for all parameters were arbitrarily chosen for the two columns of Fig. 9, and are purely for illustrative purposes. Nonetheless, this very simple model reproduces the general features observed, including a rapid diagenetic enrichment (order $10^{3} \mathrm{yr}$ ), followed by a slow decrease of $\delta^{15} \mathrm{~N}_{\text {bulk }}$ as it asymptotically approaches the $\delta^{15} \mathrm{~N}_{\text {protected }}$. 
The model is clearly a gross simplification of the complex sedimentary environment, and alternative models are feasible that could explain the data equally well. For example, there is likely to be a spectrum of protectedness (e.g. heavily silicified diatom frustules are more durable than fragile ones), and one would expect a transfer of $\mathrm{N}$ from the unprotected to the protected pool as organic molecules condense. With better understanding of the dynamics of $\mathrm{N}$ in sediments, as informed by the study of specific molecules and their $\delta^{15} \mathrm{~N}$, improved models will become possible.

\section{Conclusions}

Sedimentary $\delta^{15} \mathrm{~N}$ data from the ocean floor are now available in a single database, facilitating quantitative comparison of observations with each other and with biogeochemical ocean models. Although some regions of the seafloor are well sampled, $\delta^{15} \mathrm{~N}$ data are sparse in vast regions of the oceans, such as the southern Indian Ocean, the subtropical gyres of the Pacific, and the North Atlantic. The clustered spatial distribution is even more prevalent in the collection of subseafloor sediment records, with most sites located on the continental shelves and slopes of the Pacific, Arabian Sea and southeastern Atlantic.

Robinson et al. (2012) have shown that diagenesis during the sinking and sedimentation of organic $\mathrm{N}$ leads to an enrichment of seafloor $\delta^{15} \mathrm{~N}$ relative to the export from the surface layer. Here, we examined the subsequent changes to $\delta^{15} \mathrm{~N}$, from the seafloor to the buried sediment record. Although some regions display elevated spatial variance between neighbouring seafloor $\delta^{15} \mathrm{~N}$ measurements, reflecting strong oceanographic and/or sedimentary gradients, for most of the ocean the spatial variance is close to the measurement error over spatial scales of $100 \mathrm{~km}$, showing that individual sites are good reflections of their surroundings in most of the ocean. We tested the fidelity of the buried sedimentary $\delta^{15} \mathrm{~N}$ record by comparing the available surface data with the $\mathrm{LH}$ average from the uppermost part of subseafloor records. We found strong correlations between seafloor and subseafloor $\delta^{15} \mathrm{~N}$, which suggest reliable translation of sedimented $\delta^{15} \mathrm{~N}$ into the buried sediment record. We also discern relatively weak, but regionally coherent patterns of change between LH and seafloor sediments, suggestive of an acceleration of the marine nitrogen cycle over the late Holocene period (i.e. greater rates of water column denitrification and/or $\mathrm{N}_{2}$ fixation), rather than of significant diagenetic changes during the Holocene. However, a significant long-term diagenetic $\delta^{15} \mathrm{~N}$ decrease does appear to be present in slowly accumulating sediments of the deep sea that span multiple glacialinterglacial cycles. We speculate that this decrease is due to a gradual loss of relatively resistant, ${ }^{15} \mathrm{~N}$-enriched unprotected organic matter, under oxic conditions, though more work is required in order to test this suggestion.
This global analysis agrees with that of Robinson et al. (2012) in that, in most cases, the alteration of the sinking $\delta^{15} \mathrm{~N}$ signal by diagenesis is a secondary effect. Nonetheless, it is an effect that must be taken into account when using bulk $\delta^{15} \mathrm{~N}$ data. We suggest that the problem can be dealt with in two ways. The first way is by attempting to identify hallmarks of diagenesis where possible, in order to either exclude the data or to correct them using a mechanistic model. Identification and quantification of diagenesis could be made using bulk geochemistry (e.g. $\mathrm{C}_{\text {org }}$ vs. $\mathrm{N}_{\text {org }}$ ), amino acid analyses, or mineral-bound $\delta^{15} \mathrm{~N}$. Second, by basing any analysis on a collection of records, rather than on an individual location, different sedimentary environments (likely to display a range of diagenetic alterations) will be included. Where patterns of $\delta^{15} \mathrm{~N}$ variability over time are robust among a diversity of sedimentary environments, they are more likely to represent primary signals.

Further studies with the synthesised dataset will help to improve our understanding of the marine nitrogen cycle, and thus of ocean biogeochemical dynamics in general. The database will continue to grow as new sedimentary $\delta^{15} \mathrm{~N}$ records become available.

Acknowledgements. We thank the many investigators who contributed data to the NICOPP $\delta^{15} \mathrm{~N}$ database, through their publications, public archives, and personal correspondence. Without their willingness to share data, this compilation would not have been possible. We also gratefully acknowledge the many colleagues and sample repositories who kindly and generously shared sample material that allowed us to fill in some of the gaps in the surface sediment $\delta^{15} \mathrm{~N}$ coverage, in particular J. Arbuszewski, H. Bostock (NIWA, the National Institute of Water and Atmospheric Research), B. Conard (Deep-Sea Sample Repository at Oregon State University), A. de Vernal, T. Eglinton, L. Keigwin, K. Jarrett (Geological Survey of Canada National Marine Geoscience Collection), R. Lotti (Deep-Sea Sample Repository at Lamont-Doherty Earth Observatory), and DJW Piper. We thank PAGES, IMAGES, NSERC and CIFAR for funding.

Edited by: N. Ohkouchi

\section{References}

Agnihotri, R., Bhattacharya, S. K., Sarin, M. M., and Somayajulu, B. L. K.: Changes in surface productivity and subsurface denitrification during the Holocene: a multiproxy study from the eastern Arabian Sea, Holocene, 13, 701-713, doi:10.1191/0959683603hl656rp, 2003.

Agnihotri, R., Altabet, M. A., and Herbert, T. D.: Influence of marine denitrification on atmospheric $\mathrm{N}_{2} \mathrm{O}$ variability during the Holocene, Geophys. Res. Lett., 33, L13704, doi:10.1029/2006GL025864, 2006.

Agnihotri, R., Altabet, M. A., Herbert, T. D., and Tierney, J. E.: Subdecadally resolved paleoceanography of the Peru margin during 
the last two millennia, Geochem. Geophy. Geosy., 9, Q05013, doi:10.1029/2007GC001744, 2008a.

Agnihotri, R., Kurian, S., Fernandes, M., Reshma, K., D’Souza, W., and Naqvi, S. W. A.: Variability of subsurface denitrification and surface productivity in the coastal eastern Arabian Sea over the past seven centuries, Holocene, 18, 755-764, doi:10.1177/0959683608091795, 2008b.

Alt-Epping, U., Stuut, J. B. W., Hebbeln, D., and Schneider, R.: Variations in sediment provenance during the past 3000 years off the Tagus River, Portugal, Mar. Geol., 261, 82-91, doi:10.1016/j.margeo.2008.11.008, 2009.

Altabet, M. A.: Nitrogen isotopic evidence for micronutrient control of fractional $\mathrm{NO}_{3}^{-}$utilization in the equatorial Pacific, Limnol. Oceanogr., 46, 368-380, 2001.

Altabet, M. A.: Isotopic tracers of the marine nitrogen cycle: Present and past, in: Marine Organic Matter: Biomarkers, Isotopes and DNA, edited by: Volkman J. K., Springer, Berlin, Germany, 2006.

Altabet, M. A.: Constraints on oceanic $\mathrm{N}$ balance/imbalance from sedimentary ${ }^{15} \mathrm{~N}$ records, Biogeosciences, 4, 75-86, doi:10.5194/bg-4-75-2007, 2007.

Altabet, M. A. and Francois, R.: Sedimentary Nitrogen Isotopic Ratio as a Recorder for Surface Ocean Nitrate Utilization, Global Biogeochem. Cy., 8, 103-116, 1994.

Altabet, M. A., Francois, R., Murray, D. W., and Prell, W. L.: Climate related variations in denitrification in the Arabian Sea from sediment ${ }^{15} \mathrm{~N} /{ }^{14} \mathrm{~N}$ ratios, Nature, 373, 506-509, doi:10.1038/373506a0, 1995.

Altabet, M. A., Murray, D. W., and Prell, W. L.: Climatically linked oscillations in Arabian Sea denitrification over the past 1 m.y.: Implications for the marine N cycle, Paleoceanography, 14, 732743, doi:10.1029/1999PA900035, 1999.

Altabet, M. A., Higginson, M. J., and Murray, D. W.: The effect of millennial-scale changes in Arabian Sea denitrification on atmospheric $\mathrm{CO}_{2}$, Nature, 415, 159-162, 2002.

Altabet, M. A., Agnihotri, R., Tierny, J., Higgins, S. M., and Herbert, T. D.: A tale of two margins: A comparison of redox and productivity paleo-proxies in sediments off Oman and Peru, Geochim. Cosmochim. Ac., 69, A578-A578, 2005.

Arellano-Torres, E.: Paleoceanography of the Eastern Tropical North Pacific on millennial timescales, Ph.D. thesis, The University of Edinburgh, Edinburgh, UK, 2010.

Banakar, V. K., Oba, T., Chodankar, A. R., Kuramoto, T., Yamamoto, M., and Minagawa, M.: Monsoon related changes in sea surface productivity and water column denitrification in the Eastern Arabian Sea during the last glacial cycle, Mar. Geol., 219, 99-108, doi:10.1016/j.margeo.2005.05.004, 2005.

Bertrand, P., Pedersen, T. F., Martinez, P., Calvert, S., and Shimmield, G.: Sea level impact on nutrient cycling in coastal upwelling areas during deglaciation: Evidence from nitrogen isotopes, Global Biogeochem. Cy., 14, 341-355, doi:10.1029/1999GB900099, 2000.

Brandes, J. A. and Devol, A. H.: Isotopic fractionation of oxygen and nitrogen in coastal marine sediments, Geochim. Cosmochim. Ac., 61, 1793-1801, doi:10.1016/S0016-7037(97)00041-0, 1997.

Brandes, J. A. and Devol, A. H.: A global marine-fixed nitrogen isotopic budget: Implications for Holocene nitrogen cycling, Global Biogeochem. Cy., 16, 1120-1134, doi:10.1029/2001GB001856,
2002.

Bratton, J. F., Colman, S. M., and Seal, R. R.: Eutrophication and carbon sources in Chesapeake Bay over the last 2700 yr: Human impacts in context, Geochim. Cosmochim. Ac., 67, 3385-3402, doi:10.1016/S0016-7037(03)00131-5, 2003.

Brodie, C. R., Casford, J. S. L., Lloyd, J. M., Leng, M. J., Heaton, T. H. E., Kendrick, C. P., and Zong, Y. Q.: Evidence for bias in $\mathrm{C} / \mathrm{N}, \delta^{13} \mathrm{C}$ and $\delta^{15} \mathrm{~N}$ values of bulk organic matter, and on environmental interpretation, from a lake sedimentary sequence by pre-analysis acid treatment methods, Quaternary Sci. Rev., 30, 3076-3087, doi:10.1016/j.quascirev.2011.07.003, 2011.

Brunelle, B. G., Sigman, D. M., Cook, M. S., Keigwin, L. D., Haug, G. H., Plessen, B., Schettler, G., and Jaccard, S. L.: Evidence from diatom-bound nitrogen isotopes for subarctic $\mathrm{Pa}$ cific stratification during the last ice age and a link to North Pacific denitrification changes, Paleoceanography, 22, PA1215, doi:10.1029/2005PA001205, 2007.

Brunelle, B. G., Sigman, D. M., Jaccard, S. L., Keigwin, L. D., Plessen, B., Schettler, G., Cook, M. S., and Haug, G. H.: Glacial/interglacial changes in nutrient supply and stratification in the western subarctic North Pacific since the penultimate glacial maximum, Quaternary Sci. Rev., 29, 2579-2590, doi:10.1016/j.quascirev.2010.03.010, 2010.

Brzezinski, M. A., Pride, C. J., Franck, V. M., Sigman, D. M., Sarmiento, J. L., Matsumoto, K., Gruber, N., Rau, G. H., and Coale, K. H.: A switch from $\mathrm{Si}(\mathrm{OH})_{4}$ to $\mathrm{NO}_{3}^{-}$depletion in the glacial Southern Ocean, Geophys. Res. Lett., 29, 1564, doi:10.1029/2001GL014349, 2002.

Calvert, S. E., Nielsen, B., and Fontugne, M. R.: Evidence from nitrogen isotope ratios for enhanced productivity during formation of eastern Mediterranean sapropels, Nature, 359, 223-225. doi:10.1038/359223a0, 1992.

Calvert, S. E., Pedersen, T. F., and Karlin, R. E.: Geochemical and isotopic evidence for post-glacial palaeoceanographic changes in Saanich Inlet, British Columbia, Mar. Geol., 174, 287-305, doi:10.1016/S0025-3227(00)00156-0, 2001.

Chang, A. S., Pedersen, T. F., and Hendy, I. L.: Late Quaternary paleoproductivity history on the Vancouver Island margin, western Canada: a multiproxy geochemical study, Can. J. Earth Sci., 45, 1283-1297, doi:10.1139/E08-038, 2008.

Chazen, C. R., Altabet, M. A., and Herbert, T. D.: Abrupt mid-Holocene onset of centennial-scale climate variability on the Peru-Chile Margin, Geophys. Res. Lett., 36, L18704, doi:10.1029/2009GL039749, 2009.

De Pol-Holz, R., Ulloa, O., Lamy, F., Dezileau, L., Sabatier, P., and Hebbeln, D.: Late Quaternary variability of sedimentary nitrogen isotopes in the eastern South Pacific Ocean, Paleoceanography, 22, PA2207, doi:10.1029/2006PA001308, 2007.

Denis, D., Crosta, X., Schmidt, S., Carson, D. S., Ganeshram, R. S., Renssen, H., Crespin, J., Ther, O., Billy, I., and Giraudeau, J.: Holocene productivity changes off Adélie Land (East Antarctica), Paleoceanography, 24, PA3207, doi:10.1029/2008PA001689, 2009.

Dubois, N., Kienast, M., Kienast, S., Normandeau, C., Calvert, S. E., Herbert, T. D., and Mix, A.: Millennial-scale variations in hydrography and biogeochemistry in the Eastern Equatorial Pacific over the last $100 \mathrm{kyr}$, Quaternary Sci. Rev., 30, 210-223, doi:10.1016/j.quascirev.2010.10.012, 2011. 
Dumitrescu, M. and Brassell, S. C.: Compositional and isotopic characteristics of organic matter for the early Aptian Oceanic Anoxic Event at Shatsky Rise, ODP Leg 198, Palaeogeogr. Palaeocl., 235, 168-191, doi:10.1016/j.palaeo.2005.09.028, 2006.

Dupont, L. M., Schlutz, F., Ewah, C. T., Jennerjahn, T. C., Paul, A., and Behling, H.: Two-step vegetation response to enhanced precipitation in Northeast Brazil during Heinrich event 1, Global Change Biol., 16, 1647-1660, doi:10.1111/j.13652486.2009.02023.x, 2010.

Emeis, K. C., Struck, U., Leipe, T., and Ferdelman, T. G.: Variability in upwelling intensity and nutrient regime in the coastal upwelling system offshore Namibia: results from sediment archives, Int. J. Earth Sci., 98, 309-326, doi:10.1007/s00531007-0236-5, 2009.

Emmer, E. and Thunell, R. C.: Nitrogen isotope variations in Santa Barbara Basin sediments: Implications for denitrification in the eastern tropical North Pacific during the last 50,000 years, Paleoceanography, 15, 377-387, doi:10.1029/1999PA000417, 2000.

Etourneau, J., Martinez, P., Blanz, T., and Schneider, R.: PliocenePleistocene variability of upwelling activity, productivity, and nutrient cycling in the Benguela region, Geology, 37, 871-874, doi:10.1130/G25733A.1, 2009.

Falkowski, P. G.: Evolution of the nitrogen cycle and its influence on the biological sequestration of $\mathrm{CO}_{2}$ in the ocean, Nature, 387, 272-275, doi:10.1038/387272a0, 1997.

Farrell, J. W., Pedersen, T. F., Calvert, S. E., and Nielsen, B.: Glacial-interglacial changes in nutrient utilization in the equatorial Pacific Ocean, Nature, 377, 514-517, doi:10.1038/377514a0, 1995.

Francois, R., Bacon, M. P., Altabet, M. A., and Labeyrie, L. D.: Glacial/interglacial changes in sediment rain rate in the SW Indian sector of subantarctic waters as recorded by ${ }^{230} \mathrm{Th},{ }^{231} \mathrm{~Pa}$, U, and $\delta^{15} \mathrm{~N}$, Paleoceanography, 8, 611-629, doi:10.1029/93PA00784, 1993.

Francois, R., Altabet, M. A., Yu, E. F., Sigman, D. M., Bacon, M. P., Frank, M., Bohrmann, G., Bareille, G., and Labeyrie, L. D.: Contribution of Southern Ocean surface-water stratification to low atmospheric $\mathrm{CO}_{2}$ concentrations during the last glacial period, Nature, 389, 929-935, doi:10.1038/40073, 1997.

Freudenthal, T., Wagner T., Wenzhöfer F., Zabel, M., and Wefer, G.: Early diagenesis of organic matter from sediments of the Eastern Subtropical Atlantic: Evidence from stable nitrogen and carbon isotopes, Geochim. Cosmochim. Ac., 65, 1795-1808, doi:10.1016/S0016-7037(01)00554-3, 2001.

Freudenthal, T., Meggers, H., Henderiks, J., Kuhlmann, H., Moreno, A., and Wefer, G.: Upwelling intensity and filament activity off Morocco during the last 250,000 years, Deep-Sea Res. Part II, 49, 3655-3674, doi:10.1016/S0967-0645(02)001017, 2002.

Galbraith, E. D., Kienast, M., Pedersen, T. F., and Calvert, S. E. Glacial-interglacial modulation of the marine nitrogen cycle by high-latitude $\mathrm{O}_{2}$ supply to the global thermocline, Paleoceanography, 19, PA4007, doi:10.1029/2003PA001000, 2004.

Galbraith, E. D., Sigman, D. M., Robinson, R. S., and Pedersen, T. F.: Nitrogen in Past Marine Environments, in: Nitrogen in the Marine Environment, 2, edited by: Capone, D. G., Bronk, D. A., Mulholland, M. R., and Carpenter, E. J., Academic Press, San Diego, CA, USA, 1497-1535, 2008a.
Galbraith, E. D., Kienast, M., Jaccard, S. L., Pedersen, T. F., Brunelle, B. G., Sigman, D. M., and Kiefer, T.: Consistent relationship between global climate and surface nitrate utilization in the western subarctic Pacific throughout the last $500 \mathrm{ka}$, Paleoceanography, 23, PA2212, doi:10.1029/2007PA001518, 2008b.

Galbraith, E., Kienast, M., Albuquerque, A. S., Altabet, M. A., Bianchi, D., Quintana, S. C., De Pol-Holz, R., Dubois, N., Francois, R., Hsu, T.-C., Ivanochko, T. S., Jaccard, S. L., Kao, S.-J., Kiefer, T., Kienast, S., Lehmann, M., Martinez, P., McCarthy, M. D., Möbius, J. H., Pedersen, T. F., Quan, T. M., Robinson, R. S., Ryabenko, E., Schmittner, A., Schneider R., Schneider-Mor, A., Shigemitsu, M., Sinclair, D., Somes, C. J., Studer, A. S., Tesdal, J.-E., Thunell R. C., and Yang, J.-Y. T.: Global nitrogen isotopic constraints on the acceleration of oceanic denitrification during deglacial warming, in review, 2013.

Ganeshram, R. S., Pedersen, T. F., Calvert, S. E., and Murray, J. W.: Large changes in oceanic nutrient inventories from glacial to interglacial periods, Nature, 376, 755-758, doi:10.1038/376755a0, 1995.

Ganeshram, R. S., Pedersen, T. F., Calvert, S. E., McNeill, G. W., and Fontugne, M. R.: Glacial-interglacial variability in denitrification in the world's oceans: Causes and consequences, Paleoceanography, 15, 361-376, doi:10.1029/1999PA000422, 2000.

Gaye-Haake, B., Lahajnar, N., Emeis, K. C., Unger, D., Rixen, T., Suthhof, A., Ramaswamy, V., Schulz, H., Paropkari, A. L., Guptha, M. V. S., and Ittekkot, V.: Stable nitrogen isotopic ratios of sinking particles and sediments from the northern Indian Ocean, Mar. Chem., 96, 243-255, doi:10.1016/j.marchem.2005.02.001, 2005.

Gruber, N. and Galloway, J. N.: An Earth-system perspective of the global nitrogen cycle, Nature, 451, 293-296, doi:10.1038/nature06592, 2008.

Haug, G. H., Pedersen, T. F., Sigman, D. M., Calvert, S. E., Nielsen, B., and Peterson, L. C.: Glacial/interglacial variations in production and nitrogen fixation in the Cariaco Basin during the last 580 kyr, Paleoceanography, 13, 427-432, doi:10.1029/98PA01976, 1998.

Hendy, I. L. and Pedersen, T. F.: Oxygen minimum zone expansion in the eastern tropical North Pacific during deglaciation, Geophys. Res. Lett., 33, L20602, doi:10.1029/2006GL025975, 2006.

Hendy, I. L., Pedersen, T. F., Kennett, J. P., and Tada, R.: Intermittent existence of a southern Californian upwelling cell during submillennial climate change of the last $60 \mathrm{kyr}$, Paleoceanography, 19, PA3007, doi:10.1029/2003PA000965, 2004.

Higgins, M. B., Robinson, R. S., Carter, S. J., and Pearson, A.: Evidence from chlorin nitrogen isotopes for alternating nutrient regimes in the Eastern Mediterranean Sea, Earth Planet. Sc. Lett., 290, 102-107, doi:10.1016/j.eps1.2009.12.009, 2010.

Higginson, M. J. and Altabet, M. A.: Initial test of the silicic acid leakage hypothesis using sedimentary biomarkers, Geophys. Res. Lett., 31, L18303, doi:10.1029/2004GL020511, 2004.

Higginson, M. J., Maxwell, J. R., and Altabet, M. A.: Nitrogen isotope and chlorin paleoproductivity records from the Northern South China Sea: remote vs. local forcing of millennial- and orbital-scale variability, Mar. Geol., 201, 223250, doi:10.1016/S0025-3227(03)00218-4, 2003.

Higginson, M. J., Altabet, M. A., Murray, D. W., Murray, R. W., and Herbert, T. D.: Geochemical evidence for abrupt changes in relative strength of the Arabian monsoons during a sta- 
dial/interstadial climate transition, Geochim. Cosmochim. Ac., 68, 3807-3826, doi:10.1016/j.gca.2004.03.015, 2004.

Holmes, M. E., Schneider, R. R., Müller, P. J., Segl, M., and Wefer, G.: Reconstruction of past nutrient utilization in the eastern Angola Basin based an sedimentary ${ }^{15} \mathrm{~N} /{ }^{14} \mathrm{~N}$ ratios, Paleoceanography, 12, 604-614, doi:10.1029/97PA00819, 1997.

Huon, S., Grousset, F. E., Burdloff, D., Bardoux, G., and Mariotti, A.: Sources of fine-sized organic matter in North Atlantic Heinrich Layers: $\delta^{13} \mathrm{C}$ and $\delta^{15} \mathrm{~N}$ tracers, Geochim. Cosmochim. Ac., 66, 223-239, doi:10.1016/S0016-7037(01)00776-1, 2002.

Ivanochko, T. S. and Pedersen, T. F.: Determining the influences of Late Quaternary ventilation and productivity variations on Santa Barbara Basin sedimentary oxygenation: a multi-proxy approach, Quaternary Sci. Rev., 23, 467-480, doi:10.1016/j.quascirev.2003.06.006, 2004.

Ivanochko, T. S., Ganeshram, R. S., Brummer, G. J. A., Ganssen, G., Jung, S. J. A., Moreton, S. G., and Kroon, D.: Variations in tropical convection as an amplifier of global climate change at the millennial scale, Earth Planet. Sc. Lett., 235, 302-314, doi:10.1016/j.eps1.2005.04.002, 2005.

Jennerjahn, T. C., Ittekkot, V., Arz, H. W., Behling, H., Pätzold, J., and Wefer, G.: Asynchronous terrestrial and marine signals of climate change during Heinrich events, Science, 306, 22362239, doi:10.1126/science.1102490, 2004.

Jia, G. and Li, Z.: Easterly denitrification signal and nitrogen fixation feedback documented in the western Pacific sediments, Geophys. Res. Lett., 38, L24605, doi:10.1029/2011GL050021, 2011.

Kao, S. J., Liu, K. K., Hsu, S. C., Chang, Y. P., and Dai, M. H.: North Pacific-wide spreading of isotopically heavy nitrogen during the last deglaciation: Evidence from the western Pacific, Biogeosciences, 5, 1641-1650, doi:10.5194/bg-5-1641-2008, 2008.

Kessarkar, P. M., Rao, V. P., Naqvi, S. W. A., Chivas, A. R., and Saino, T.: Fluctuations in productivity and denitrification in the southeastern Arabian Sea during the Late Quaternary, Curr. Sci. India, 99, 485-491, 2010.

Kienast, M.: Unchanged nitrogen isotopic composition of organic matter in the South China Sea during the last climatic cycle: Global implications, Paleoceanography, 15, 244-253, doi:10.1029/1999PA000407, 2000.

Kienast, M., Higginson, M. J., Mollenhauer, G., Eglinton, T. I., Chen, M. T., and Calvert, S. E.: On the sedimentological origin of down-core variations of bulk sedimentary nitrogen isotope ratios, Paleoceanography, 20, PA2009, doi:10.1029/2004PA001081, 2005.

Kienast, M., Lehmann, M. F., Timmermann, A., Galbraith, E., Bolliet, T., Holboum, A., Normandeau, C., and Laj, C.: A midHolocene transition in the nitrogen dynamics of the western equatorial Pacific: Evidence of a deepening thermocline?, Geophys. Res. Lett., 35, L23610, doi:10.1029/2008GL035464, 2008.

Kienast, S. S., Calvert, S. E., and Pedersen, T. F.: Nitrogen isotope and productivity variations along the northeast Pacific margin over the last $120 \mathrm{kyr}$ : Surface and subsurface paleoceanography, Paleoceanography, 17, 1055, doi:10.1029/2001PA000650, 2002.

Kim, S., Khim, B. K., Uchida, M., Itaki, T., and Tada, R.: Millennial-scale paleoceanographic events and implication for the intermediate-water ventilation in the northern slope area of the Bering Sea during the last 71 kyrs, Global Planet. Change, 79, 89-98, doi:10.1016/j.gloplacha.2011.08.004, 2011.
Knapp, A. N., Hastings, M. G., Sigman, D. M., Lipschultz, F., and Galloway, J. N.: The flux and isotopic composition of reduced and total nitrogen in Bermuda rain, Mar. Chem., 120, 83-89, doi:10.1016/j.marchem.2008.08.007, 2010.

Langton, S. J., Linsley, B. K., Robinson, R. S., Rosenthal, Y., Oppo, D. W., Eglinton, T. I., Howe, S. S., Djajadihardja, Y. S., and Syamsudin, F.: 3500 yr record of centennial-scale climate variability from the Western Pacific Warm Pool, Geology, 36, 795798, doi:10.1130/G24926A.1, 2008.

Lisiecki, L. E. and Raymo, M. E.: A Pliocene-Pleistocene stack of 57 globally distributed benthic $\delta^{18} \mathrm{O}$ records, Paleoceanography, 20, PA1003, doi:10.1029/2004PA001071, 2005.

Liu, Z. H., Altabet, M. A., and Herbert, T. D.: Plio-Pleistocene denitrification in the eastern tropical North Pacific: Intensification at 2.1 Ma, Geochem. Geophy. Geosy., 9, Q11006, doi:10.1029/2008GC002044, 2008.

Lourey, M. J., Trull, T. W., and Sigman, D. M.: Sensitivity of $\delta^{15} \mathrm{~N}$ of nitrate, surface suspended and deep sinking particulate nitrogen to seasonal nitrate depletion in the Southern Ocean, Global Biogeochem. Cy., 17, 1081, doi:10.1029/2002GB001973, 2003.

Martinez, P., Bertrand, P., Calvert, S. E., Pedersen, T. F., Shimmield, G. B., Lallier-Vergès, E., and Fontugne, M. R.: Spatial variations in nutrient utilization, production and diagenesis in the sediments of a coastal upwelling regime (NW Africa): Implications for the paleoceanographic record, J. Mar. Res., 58, 809835, doi:10.1357/002224000321358927, 2000.

Martinez, P., Lamy, F., Robinson, R. R., Pichevin, L., and Billy, I.: Atypical $\delta^{15} \mathrm{~N}$ variations at the southern boundary of the East Pacific oxygen minimum zone over the last $50 \mathrm{ka}$, Quaternary Sci. Rev., 25, 3017-3028, doi:10.1016/j.quascirev.2006.04.009, 2006.

McClelland, J. W. and Montoya, J. P.: Trophic relationships and the nitrogen isotopic composition of amino acids in plankton, Ecology, 83, 2173-2180, doi:10.2307/3072049, 2002.

McKay, J. L., Pedersen, T. F., and Kienast, S. S.: Organic carbon accumulation over the last $16 \mathrm{kyr}$ off Vancouver Island, Canada: evidence for increased marine productivity during the deglacial, Quaternary Sci. Rev., 23, 261-281, doi:10.1016/j.quascirev.2003.07.004, 2004.

Meckler, A. N., Haug, G. H., Sigman, D. M., Plessen, B., Peterson, L. C., and Thierstein, H. R.: Detailed sedimentary N isotope records from Cariaco Basin for terminations I and V: Local and global implications, Global Biogeochem. Cy., 21, GB4019, doi:10.1029/2006GB002893, 2007.

Meckler, A. N., Ren, H. J., Sigman, D. M., Gruber, N., Plessen, B., Schubert, C. J., and Haug, G. H.: Deglacial nitrogen isotope changes in the Gulf of Mexico: Evidence from bulk sedimentary and foraminifera-bound nitrogen in Orca Basin sediments, Paleoceanography, 26, PA4216, doi:10.1029/2011PA002156, 2011.

Milder, J. C., Montoya, J. P., and Altabet, M. A.: Carbon and nitrogen stable isotope ratios at sites 969 and 974: Interpreting spatial gradients in sapropel properties, in: Proceedings of the Ocean Drilling Program, Scientific Results, Vol. 161, College Station, TX (Ocean Drilling Program), edited by: Zahn, R., Comas, M. C., and Klaus, A., 401-411, doi:10.2973/odp.proc.sr.161.271.1999, 1999.

Minagawa, M., Winter, D. A., and Kaplan, I. R.: Comparison of Kjeldahl and combustion methods for measurement of nitrogen isotope ratios in organic matter, Anal. Chem., 56, 1859-1861, 
doi:10.1021/ac00275a023, 1984.

Möbius, J., Gaye, B., Lahajnar, N., Bahlmann, E., and Emeis, K. C.: Influence of diagenesis on sedimentary $\delta^{15} \mathrm{~N}$ in the Arabian Sea over the last $130 \mathrm{kyr}$, Mar. Geol., 284, 127-138, doi:10.1016/j.margeo.2011.03.013, 2011.

Müller, A. and Opdyke, B. N.: Glacial-interglacial changes in nutrient utilization and paleoproductivity in the Indonesian Throughflow sensitive Timor Trough, easternmost Indian Ocean, Paleoceanography, 15, 85-94, doi:10.1029/1999PA900046, 2000.

Nakatsuka, T., Harada, N., Matsumoto, E., Handa, N., Oba, T., Ikehara, M., Matsuoka, H., and Kimoto, K.: Glacial-interglacial migration of an upwelling field in the western equatorial Pacific recorded by sediment ${ }^{15} \mathrm{~N} /{ }^{14} \mathrm{~N}$, Geophys. Res. Lett., 22, $2525-$ 2528, doi:10.1029/95GL02544, 1995a.

Nakatsuka, T., Watanabe, K., Handa, N., Matsumoto, E., and Wada, E.: Glacial to interglacial surface nutrient variations of Bering deep basins recorded by $\delta^{13} \mathrm{C}$ and $\delta^{15} \mathrm{~N}$ of sedimentary organic matter, Paleoceanography, 10, 1047-1061, doi:10.1029/95PA02644, 1995b.

Needoba, J. A., Sigman, D. M., and Harrison, P. J.: The mechanism of isotope fractionation during algal nitrate assimilation as illuminated by the ${ }^{15} \mathrm{~N} /{ }^{14} \mathrm{~N}$ of intracellular nitrate, J. Phycol., 40, 517-522, doi:10.1111/j.1529-8817.2004.03172.x, 2004.

Parsons, M. A., Duerr, R., and Minister, J. B.: Data citation and peer review, Eos, Transactions of the American Geophysical Union, 91, 297-298, doi:10.1029/2010EO340001, 2010.

Pedersen, A. G. U., Thomsen, T. R., Lomstein, B. A., and Jørgensen, N. O. G.: Bacterial influence on amino acid enantiomerization in a coastal marine sediment, Limnol. Oceanogr., 46, 1358-1369, 2001.

Petit, J. R., Jouzel, J., Raynaud, D., Barkov, N. I., Barnola, J.M., Basile, I., Bender, M., Chappellaz, J., Davis, M., Delaygue, G., Delmotte, M., Kotlyakov, V. M., Legrand, M., Lipenkov, V. Y., Lorius, C., Pépin, L., Ritz, C., Saltzman, E., and Stievenard, M.: Climate and atmospheric history of the past 420,000 years from the Vostok ice core, Antarctica, Nature, 399, 429436, doi:10.1038/20859, 1999.

Pichevin, L., Martinez, P., Bertrand, P., Schneider, R., Giraudeau, J., and Emeis, K.: Nitrogen cycling on the Namibian shelf and slope over the last two climatic cycles: Local and global forcings, Paleoceanography, 20, PA2006, doi:10.1029/2004PA001001, 2005.

Pichevin, L., Bard, E., Martinez, P., and Billy, I.: Evidence of ventilation changes in the Arabian Sea during the late Quaternary: Implication for denitrification and nitrous oxide emission, Global Biogeochem. Cy., 21, GB4008, doi:10.1029/2006GB002852, 2007.

Pichevin, L. E., Reynolds, B. C., Ganeshram, R. S., Cacho, I., Pena, L., Keefe, K., and Ellam, R. M.: Enhanced carbon pump inferred from relaxation of nutrient limitation in the glacial ocean, Nature, 459, 1114-1118, doi:10.1038/nature08101, 2009.

Pichevin, L. E., Ganeshram, R. S., Francavilla, S., Arellano-Torres, E., Pedersen, T. F., and Beaufort, L.: Interhemispheric leakage of isotopically heavy nitrate in the eastern tropical Pacific during the last glacial period, Paleoceanography, 25, PA1204, doi:10.1029/2009PA001754, 2010.

Presti, M., Barbara, L., Denis, D., Schmidt, S., De Santis, L., and Crosta, X.: Sediment delivery and depositional patterns off Adélie Land (East Antarctica) in relation to late Quaternary climatic cycles, Mar. Geol., 284, 96-113, doi:10.1016/j.margeo.2011.03.012, 2011.

Pride, C., Thunell, R., Sigman, D., Keigwin, L., Altabet, M., and Tappa, E.: Nitrogen isotopic variations in the Gulf of California since the last deglaciation: Response to global climate change, Paleoceanography, 14, 397-409, doi:10.1029/1999PA900004, 1999.

Rau, G. H., Arthur, M. A., and Dean, W. E.: ${ }^{15} \mathrm{~N} /{ }^{14} \mathrm{~N}$ variations in Cretaceous Atlantic sedimentary sequences: implication for past changes in marine nitrogen biogeochemistry, Earth Planet. Sc. Lett., 82, 269-279, doi:10.1016/0012-821X(87)90201-9, 1987.

Rau, A. J.: A late quaternary history of Agulhas-Benguela interactions from two sediment cores on the western continental slope of South Africa, Ph.D., University of Cape Town, Cape Town, South Africa, 2002.

Rau, A. J., Rogers, J., Lutjeharms, J. R. E., Giraudeau, J., LeeThorp, J. A., Chen, M. T., and Waelbroeck, C.: A 450-kyr record of hydrological conditions on the western Agulhas Bank Slope, south of Africa, Mar. Geol., 180, 183-201, doi:10.1016/S00253227(01)00213-4, 2002.

Reichart, G. J., Lourens, L. J., and Zachariasse, W. J.: Temporal variability in the northern Arabian Sea Oxygen Minimum Zone (OMZ) during the last 225,000 years, Paleoceanography, 13, 607-621, doi:10.1029/98PA02203, 1998.

Ren, H., Sigman, D. M., Meckler, A. N., Plessen, B., Robinson, R. S., Rosenthal, Y., and Haug, G. H.: Foraminiferal isotope evidence of reduced nitrogen fixation in the ice age Atlantic Ocean, Science, 323, 244-248, doi:10.1126/science.1165787, 2009.

Robinson, R. S. and Meyers, P. A.: Biogeochemical changes within the Benguela Current upwelling system during the Matuyama Diatom Maximum: Nitrogen isotope evidence from Ocean Drilling Program Sites 1082 and 1084, Paleoceanography, 17, 1064, doi:10.1029/2001PA000659, 2002.

Robinson, R. S., Sigman, D. M., DiFiore, P. J., Rohde, M. M., Mashiotta, T. A., and Lea, D. W.: Diatom-bound ${ }^{15} \mathrm{~N} /{ }^{14} \mathrm{~N}$ : New support for enhanced nutrient consumption in the ice age subantarctic, Paleoceanography, 20, PA3003, doi:10.1029/2004PA001114, 2005.

Robinson, R. S., Mix, A., and Martinez, P.: Southern Ocean control on the extent of denitrification in the southeast Pacific over the last $70 \mathrm{ka}$, Quaternary Sci. Rev., 26, 201-212, doi:10.1016/j.quascirev.2006.08.005, 2007.

Robinson, R. S., Martinez, P., Pena, L. D., and Cacho, I.: Nitrogen isotopic evidence for deglacial changes in nutrient supply in the eastern equatorial Pacific, Paleoceanography, 24, PA4213, doi:10.1029/2008PA001702, 2009.

Robinson, R. S., Kienast, M., Albuquerque, A. L., Altabet, M. A., Contreras, S., De Pol-Holz, R., Dubois, N., Francois, R., Galbraith, E., Hsu, T.-C., Ivanochko, T., Jaccard, S., Kao, S.-J., Kiefer, T., Kienast, S., Lehmann, M. F., Martinez, P., McCarthy, M., Möbius, J., Pedersen, T., Quan, T. M., Ryabenko, E., Schmittner, A., Schneider R., Schneider-Mor, A., Shigemitsu, M., Sinclair, D., Somes, C., Studer, A., Thunell R., and Yang, J.-Y.: A review of nitrogen isotopic alteration in marine sediments, Paleoceanography, 27, PA4203, doi:10.1029/2012PA002321, 2012.

Schubert, C. J. and Calvert, S. E.: Nitrogen and carbon isotopic composition of marine and terrestrial organic matter in Arctic Ocean sediments: implications for nutrient utilization and organic matter composition, Deep-Sea Res. Part I, 48, 789-810, doi:10.1016/S0967-0637(00)00069-8, 2001. 
Schubert, C. J., Stein, R., and Calvert, S. E.: Tracking nutrient and productivity variations over the last deglaciation in the Arctic Ocean, Paleoceanography, 16, 199-211, doi:10.1029/2000PA000503, 2001.

Shigemitsu, M., Watanabe, Y. W., and Narita, H.: Time variations of $\delta^{15} \mathrm{~N}$ of organic nitrogen in deep western subarctic Pacific sediment over the last $145 \mathrm{ka}$, Geochem. Geophy. Geosy., 9, Q10012, doi:10.1029/2008GC001999, 2008.

Sigman, D. M., Altabet, M. A., Michener, R., McCorkle, D. C., Fry, B., and Holmes, R. M.: Natural abundance-level measurement of the nitrogen isotopic composition of oceanic nitrate: an adaptation of the ammonia diffusion method, Mar. Chem., 57, 227-242, 1997.

Sigman, D. M., Altabet, M. A., McCorkle, D. C., Francois, R., and Fischer, G.: The $\delta^{15} \mathrm{~N}$ of nitrate in the Southern Ocean: Consumption of nitrate in surface waters, Global Biogeochem. Cy., 13, 1149-1166, doi:10.1029/1999GB900038, 1999.

Sigman, D. M., Jaccard, S. L., and Haug, G. H.: Polar ocean stratification in a cold climate, Nature, 428, 59-63, doi:10.1038/nature02357, 2004.

Somes, C. J., Schmittner, A., Galbraith, E. D., Lehmann, M. F., Altabet, M. A., Montoya, J. P., Letelier, R. M., Mix, A. C., Bourbonnais, A., and Eby, M.: Simulating the global distribution of nitrogen isotopes in the ocean, Global Biogeochem. Cy., 24, GB4019, doi:10.1029/2009GB003767, 2010.

Struck, U., Emeis, K. C., Voss, M., Krom, M. D., and Rau, G. H.: Biological productivity during sapropel S5 formation in the Eastern Mediterranean Sea: Evidence from stable isotopes of nitrogen and carbon, Geochim. Cosmochim. Ac., 65, 3249-3266, doi:10.1016/S0016-7037(01)00668-8, 2001.
Struck, U., Altenbach, A. V., Emeis, K. C., Alheit, J., Eichner, C., and Schneider, R.: Changes of the upwelling rates of nitrate preserved in the $\delta^{15} \mathrm{~N}$-signature of sediments and fish scales from the diatomaceous mud belt of Namibia, Geobios-Lyon, 35, 3-11, doi:10.1016/S0016-6995(02)00004-9, 2002.

Suthhof, A., Ittekkot, V., and Gaye-Haake, B.: Millennial-scale oscillation of denitrification intensity in the Arabian Sea during the late Quaternary and its potential influence on atmospheric $\mathrm{N}_{2} \mathrm{O}$ and global climate, Global Biogeochem. Cy., 15, 637-649, doi:10.1029/2000GB001337, 2001.

Thunell, R. C. and Kepple, A. B.: Glacial-Holocene $\delta^{15} \mathrm{~N}$ record from the Gulf of Tehuantepec, Mexico: Implications for denitrification in the eastern equatorial Pacific and changes in atmospheric $\mathrm{N}_{2} \mathrm{O}$, Global Biogeochem. Cy., 18, GB1001, doi:10.1029/2002GB002028, 2004.

Thunell, R. C., Sigman, D. M., Muller-Karger, F., Astor, Y., and Varela, R.: Nitrogen isotope dynamics of the Cariaco Basin, Venezuela, Global Biogeochem. Cy., 18, GB3001, doi:10.1029/2003GB002185, 2004.

Tiwari, M., Ramesh, R., Bhushan, R., Sheshshayee, M. S., Somayajulu, B. L. K., Jull, A. J. T., and Burr, G. S.: Did the Indo-Asian summer monsoon decrease during the Holocene following insolation?, J. Quaternary Sci., 25, 1179-1188, doi:10.1002/jqs.1398, 2010.

Westrich, J. T. and Berner, R. A.: The role of sedimentary organic matter in bacterial sulfate reduction: The $\mathrm{G}$ model tested, Limnol. Oceanogr., 29, 236-249, 1984. 